\title{
Presence of Tetracycline and Sulfonamide Resistance Genes in Salmonella spp.: Literature Review
}

\author{
Sabrina Lunara Santos Pavelquesi $(\mathbb{D}$, Ana Carolina Almeida de Oliveira Ferreira, \\ Angeislenie Ricelle Magalhães Rodrigues, Calliandra Maria de Souza Silva $\mathbb{D}$, Daniela Castilho Orsi *(D) \\ and Izabel Cristina Rodrigues da Silva (i)
}

Laboratory of Food Control, University of Brasilia (UnB), Centro Metropolitano, Conjunto A, lote 01, Ceilandia, Brasilia CEP, Brasília 72220-900, DF, Brazil; sabrinalunara@gmail.com (S.L.S.P.); acarolina.olive@gmail.com (A.C.A.d.O.F.); ricelle@unb.br (A.R.M.R.); cdssilva@gmail.com (C.M.d.S.S.); belbiomedica@gmail.com (I.C.R.d.S.)

* Correspondence: danielacastilhoorsi@gmail.com; Tel.: +55-061-983128359

check for updates

Citation: Pavelquesi, S.L.S.; de Oliveira Ferreira, A.C.A.; Rodrigues, A.R.M.; de Souza Silva, C.M.; Orsi, D.C.; da Silva, I.C.R. Presence of Tetracycline and Sulfonamide Resistance Genes in Salmonella spp.: Literature Review. Antibiotics 2021, 10, 1314. https://doi.org/10.3390/ antibiotics10111314

Received: 10 September 2021 Accepted: 20 October 2021 Published: 28 October 2021

Publisher's Note: MDPI stays neutral with regard to jurisdictional claims in published maps and institutional affiliations.

Copyright: (c) 2021 by the authors. Licensee MDPI, Basel, Switzerland. This article is an open access article distributed under the terms and conditions of the Creative Commons Attribution (CC BY) license (https:// creativecommons.org/licenses/by/ $4.0 /)$.

\begin{abstract}
Tetracyclines and sulfonamides are broad-spectrum antibacterial agents which have been used to treat bacterial infections for over half a century. The widespread use of tetracyclines and sulfonamides led to the emergence of resistance in a diverse group of bacteria. This resistance can be studied by searching for resistance genes present in the bacteria responsible for different resistance mechanisms. Salmonella is one of the leading bacteria causing foodborne diseases worldwide, and its resistance to tetracyclines and sulfonamides has been widely reported. The literature review searched the Virtual Health Library for articles with specific data in the studied samples: the resistance genes found, the primers used in PCR, and the thermocycler conditions. The results revealed that Salmonella presented high rates of resistance to tetracycline and sulfonamide, and the most frequent samples used to isolate Salmonella were poultry and pork. The tetracycline resistance genes most frequently detected from Salmonella spp. were tet $A$ followed by tetB. The gene sul1 followed by sul 2 were the most frequently sulfonamide resistance genes present in Salmonella. These genes are associated with plasmids, transposons, or both, and are often conjugative, highlighting the transference potential of these genes to other bacteria, environments, animals, and humans.
\end{abstract}

Keywords: tetracycline; sulfonamide; Salmonella; antibiotic resistance

\section{Introduction}

Tetracyclines are broad-spectrum antibacterial agents, which show activity against most Gram-positive and Gram-negative bacteria, both anaerobic and aerobic. The tetracyclines mode of action is well established; they inhibit bacterial protein synthesis by avoiding the association between RNA molecules and the $30 \mathrm{~S}$ subunit of the bacterial ribosome, thus preventing the addition of amino acids and, consequently, protein synthesis [1-6].

Sulfonamides are synthetic antibacterial drugs presenting a para-amino benzoic acid (PABA) structure and containing a sulfonamide group linked to an aromatic group that competitively inhibits the enzyme dihydropteroate synthase (DHPS). DHPS participates in folate synthesis, an essential mechanism for bacterial DNA and RNA synthesis, using PABA as a substrate, and this competitive inhibition of DHPS by sulfonamides inhibits bacterial growth [7-10]. Consequently, these drugs have activity against a broad spectrum of bacteria, being able to inhibit both Gram-negative and Gram-positive bacteria that do not possess mechanisms to overcome the inhibition effects of DHPS [11].

Sulfonamides were the first drugs to be used in veterinary medicine in therapeutic doses [12,13]. Their excessive usage imposed widespread selective pressures on bacteria, as seen by the high prevalence rates of sulfonamide resistance observed in mainly Gram-negative bacteria isolated from animals and humans all over the world in the past decade [14-17]. Another concern is the accumulation of sulfonamides as environmental 
contaminants. Sulfonamides were a high priority of veterinary medicines, due to their high potential to reach the environment $[18,19]$. Sulfonamides are excreted after consumption and consequently, can be found at high concentrations in livestock wastewaters [20-22]. The accumulation of sulfonamides as environmental contaminants is potentiated by their resistance to degradation during conventional wastewater treatments [23]. In addition to the direct environmental adverse impacts, high sulfonamide concentrations increase the risks of food chain contamination [11].

Since the introduction of tetracyclines in 1950, their combination of broad-spectrum activity and low toxicity has led to their intensive use in human and animal infections therapy, and they have also been used for nearly as long to promote growth in food animal production systems [1]. The growth-promoting properties of tetracyclines were first described in 1949 for chickens, and farmers widely used them in animal husbandry thanks to improvement of the growth rate to feed intake ratio [12,13]. This extensive use favored the emergence of tetracycline resistance in a diverse group of bacteria and caused restrictions on the clinical utility of these compounds [2,3].

Tetracycline resistance in most bacteria is due to the acquisition of mobile genetic elements, ribosomal binding site mutations and chromosomal mutations leading to increased expression of intrinsic resistance mechanisms. Three principal tetracycline resistance mechanisms are efflux pumps, ribosomal protection, and enzymatic inactivation of tetracyclines drugs $[1,3,24,25]$. Several different tet genes have been described as conferring resistance to tetracyclines in bacteria. The most frequent types of tet genes belong to classes A, B, C, D and G [26], and these genes are responsible for encoding tetracycline efflux pumps $[4,5,27,28]$. Recent articles show that Salmonella spp. resistance to tetracycline is frequently found in analyzed samples, and this resistance is due mainly to the presence of tet genes in these bacteria. The tet $A$, tet $B$, tet $C$ and tet $D$ genes were detected on different S. enterica bacteria serotypes, including Typhimurium, Enteritidis, Hadar, Saintpaul and Choleraesuis [25,28-30].

Resistance to sulfonamides in Gram-negative bacteria is associated with the presence of sul genes that encode dihydropteroate synthase in a form that the drug cannot inhibit. There are four sul genes (sul1, sul2, sul3 and sul4) that encode resistance to sulfonamides [7,10]. The sul1 and sul2 genes have previously been identified in Enterobacteriaceae, particularly Escherichia and Salmonella [10]. In 2003, Perreten and Boerlin [31] reported the sul3 gene, detected in Escherichia coli isolated from pigs in Switzerland. In 2017, Razavi et al. [32] described the sul4 gene, which provided clinical resistance in Enterobacteriaceae. Sul genes can be transferred between bacteria via integrons, transposons or plasmids [10]. According to Guerra et al. [33] the sul3 gene can be detected in Salmonella spp. strains of different origins and serotypes on various large plasmids. However, dissemination of sul1 and sul2 genes among Salmonella spp. is reported more often than the sul3 gene [7].

Salmonella is one of the most common bacteria that causes foodborne diseases worldwide [34]. The latest Brazilian foodborne disease national survey [35] reveals that, in the last nine years, Salmonella spp. was the second most common etiological agent identified in foodborne disease outbreaks in Brazil. Hoffmann et al. [36] reported that Salmonella causes more than one million diseases in the United States per year. Reports from the European Union in 2019 showed 87,923 confirmed cases of salmonellosis in humans, measuring up to $17.9 \%$ of foodborne outbreaks that year, with an observed overall high level of resistance to ampicillin, tetracyclines, and sulfonamides [37].

Some studies have shown that Salmonella has a higher percentage of tetracycline [38-42] and sulfonamide $[7,14,16,21,43]$ resistance. There is a growing concern about the overall increase in bacterial resistance to antibiotics. Several studies have documented the transfer of antibiotic-resistant bacteria from animals to the human population, posing a serious threat to public health $[43,44]$. In this context, a literature review on the presence of tetracycline and sulfonamide resistance genes in Salmonella spp. was performed. 


\section{Materials and Methods}

\subsection{Search Strategy}

The bibliographic search was conducted through the Virtual Health Library (VHL), a portal where bibliographic reference databases and full texts are available to search for physical and digital books, booklets, manuals, magazines, and legislation, among other services. VHL also accesses international databases such as Medline and Lilacs, among others. Publications relating antimicrobial resistance genes for Salmonella spp. were screened using the following terms: "tetracycline resistance genes", "sulfonamide resistance genes" and "Salmonella". The retrieved publications were selected to be studied.

\subsection{Filters, Inclusion and Exclusion Criteria}

According to the research interest, the terms were searched in the database from 2009 to 2019. The inclusion criteria were as follows: (1) the type of sample studied must have been reported; (2) the resistance genes sought; (3) the primers used in the polymerase chain reaction (PCR); and (4) thermocycler and PCR conditions. Studies were excluded if: (1) they had sought the resistance gene but did not present the primer sequence used in PCR; (2) the resistance gene was not towards tetracycline or sulfonamide; and (3) they did not have the thermocycler conditions used in PCR.

\subsection{Data Extraction}

Data were extracted from eligible studies according to the research criteria. For each study, the following characteristics were collected: the authors, the title of the study, the year of publication, the type of sample studied, the sample size, the resistance gene, the primers sequence of the genes, the thermocycler and PCR conditions, as well as the results.

\section{Results and Discussion}

Prevalence of tetracycline and sulfonamide resistant Salmonella spp. strains and distribution of tetracycline and sulfonamide resistance genes.

The search for articles associated with tetracycline and/or sulfonamide resistance genes to Salmonella spp. resulted in 25 studies that met the inclusion criteria (presented tetracycline and/or sulfonamide resistance genes, presented the primer sequence used in PCR and specified the thermocycler conditions used in PCR). Of the 25 studies, 6 searched for tet genes, 3 searched for sul genes, and 16 searched for both tet and sul genes. The general characteristics of the studies included in this review are summarized in Table 1.

Table 1. Summary of studies with tetracycline and sulfonamide resistance genes in Salmonella spp.

\begin{tabular}{|c|c|c|c|c|c|}
\hline Studies & Authors & Title & Year & Genes Searched & Reference \\
\hline 1 & Aslam et al. & $\begin{array}{l}\text { Phenotypic and genetic characterization of } \\
\text { antimicrobial resistance in Salmonella serovars } \\
\text { isolated from retail meats in Alberta, Canada }\end{array}$ & 2012 & $\begin{array}{c}\text { tet } A, \text { tet } B, \text { tet } C, \text { sul1 } \\
\text { sul2, sul3 }\end{array}$ & {$[45]$} \\
\hline 2 & Dahshan et al. & $\begin{array}{c}\text { Characterization of antibiotic resistance and the } \\
\text { emergence of AmpC-producing Salmonella } \\
\text { infantis from pigs }\end{array}$ & 2010 & tet $A$, tet $B$, tet $G$, sul 1 & [46] \\
\hline 3 & Deng et al. & $\begin{array}{l}\text { Antibiotic resistance in Salmonella from retail } \\
\text { foods of animal origin and its association with } \\
\text { disinfectant and heavy metal resistance }\end{array}$ & 2017 & $\begin{array}{l}\text { tet } A, \text { tet } B, \text { tet } C, \text { tet } G \\
\text { sull }, \text { sul } 2, \text { sul3 }\end{array}$ & [38] \\
\hline 4 & Dessie et al. & $\begin{array}{c}\text { Characterization of integrons and their cassettes } \\
\text { in Escherichia coli and Salmonella isolates from } \\
\text { poultry in Korea }\end{array}$ & 2013 & $\begin{array}{l}\text { tet } A, \text { tet } B, \text { tet } C, \\
\text { tet } D, \text { tet } E, \text { tet } G \\
\text { sull, sul } 2\end{array}$ & [27] \\
\hline 5 & El-Sharkawy et al. & $\begin{array}{l}\text { Epidemiological, molecular characterization and } \\
\text { antibiotic resistance of Salmonella enterica } \\
\text { serovars isolated from chicken farms in Egypt }\end{array}$ & 2017 & $\begin{array}{c}\text { tet } A, \text { tet } B, \text { tet } C, \text { sull } \\
\text { sul2, sul3 }\end{array}$ & [47] \\
\hline
\end{tabular}


Table 1. Cont.

\begin{tabular}{|c|c|c|c|c|c|}
\hline Studies & Authors & Title & Year & Genes Searched & Reference \\
\hline 6 & Hsu et al. & $\begin{array}{c}\text { Antibiotic resistance pattern and gene expression } \\
\text { of non-typhoid Salmonella in river sheds }\end{array}$ & 2014 & tet $A$, tet $B$, sul1 & [48] \\
\hline 7 & Igbinosa & $\begin{array}{l}\text { Prevalence and detection of antibiotic-resistant } \\
\text { determinant in Salmonella isolated from } \\
\text { food-producing animals }\end{array}$ & 2014 & tet $C$ & [44] \\
\hline 8 & Iwu et al. & $\begin{array}{l}\text { Multidrug-resistant Salmonella isolates from } \\
\text { swine in the Eastern Cape Province, South Africa }\end{array}$ & 2016 & tet $A$ & [39] \\
\hline 9 & Khoshbakht et al. & $\begin{array}{l}\text { Tetracycline resistance genes in Salmonella } \\
\text { enterica serovars with animal and human origin }\end{array}$ & 2018 & tet $A$, tet $B$, tet $C$, tet $G$ & [49] \\
\hline 10 & Kozak et al. & $\begin{array}{c}\text { Distribution of sulfonamide resistance genes in } \\
\text { Escherichia coli and Salmonella isolates from swine } \\
\text { and chickens at Abattoirs in Ontario and } \\
\text { Québec, Canada }\end{array}$ & 2009 & sul1, sul2, sul3 & {$[50]$} \\
\hline 11 & Lapierre et al. & $\begin{array}{l}\text { Comparison of integron-linked antibiotic } \\
\text { resistance genes in strains of Salmonella spp. } \\
\text { isolated from swine in Chile in } 2005 \text { and } 2008\end{array}$ & 2010 & tet $A$, tet $B$, tet $G$ & {$[51]$} \\
\hline 12 & Lopes et al. & $\begin{array}{l}\text { Resistance phenotypes and genotypes of } \\
\text { Salmonella enterica subsp. enterica isolates from } \\
\text { feed, pigs, and carcasses in Brazil }\end{array}$ & 2015 & $\begin{array}{l}\text { tet } A, \text { tet } B, \text { sul1, } \\
\quad \text { sul2, sul3 }\end{array}$ & [52] \\
\hline 13 & Maka et al. & $\begin{array}{l}\text { Resistance to sulfonamides and dissemination of } \\
\text { sul genes among Salmonella spp. isolated from } \\
\text { food in Poland }\end{array}$ & 2015 & sul1, sul2, sul3 & [7] \\
\hline 14 & Marquéz et al. & $\begin{array}{l}\text { Biocide tolerance and antibiotic resistance in } \\
\text { Salmonella isolates from hen eggshells }\end{array}$ & 2017 & $\begin{array}{l}\text { tet } A, \text { tet } B, \text { tet } C \\
\text { tet } D, \text { tet } E, \text { tet } G, \text { sul1 }\end{array}$ & [53] \\
\hline 15 & Mthembu et al. & $\begin{array}{l}\text { Molecular detection of multidrug-resistant } \\
\text { Salmonella isolated from livestock production } \\
\text { systems in South Africa }\end{array}$ & 2019 & tet $A$, tetC, sul2 & {$[54]$} \\
\hline 16 & Sadiq et al. & $\begin{array}{c}\text { Antibacterial activities and possible modes of } \\
\text { action of Acacia nilotica (L.) Del. against } \\
\text { multidrug-resistant Escherichia coli } \\
\text { and Salmonella }\end{array}$ & 2017 & tet $A$, tet $B$ & [40] \\
\hline 17 & Soyer et al. & $\begin{array}{l}\text { Antimicrobial drug resistance patterns among } \\
\text { cattle-and human-associated Salmonella strains }\end{array}$ & 2013 & $\begin{array}{l}\text { tet } A, \text { tet } B, \text { tet } G \\
\text { sul } 1, \text { sul } 2\end{array}$ & [55] \\
\hline 18 & Tajbakhsh et al. & $\begin{array}{l}\text { Antimicrobial resistance in Salmonella spp. } \\
\text { recovered from patients admitted to six different } \\
\text { hospitals in Tehran, Iran from } 2007 \text { to } 2008\end{array}$ & 2012 & $\begin{array}{l}\text { tet } A, \text { tet } B, \text { tet } C \text {, } \\
\text { tet } D, \text { tet } G, \text { sul1 }\end{array}$ & {$[56]$} \\
\hline 19 & Thai et al. & $\begin{array}{c}\text { Antimicrobial resistance in Salmonella serovars } \\
\text { isolated from meat shops at markets in } \\
\text { North Vietnam. }\end{array}$ & 2012 & tet $A$, tet $B$, tet $G$, sul1 & [57] \\
\hline 20 & Vital et al. & $\begin{array}{l}\text { Antimicrobial resistance in Escherichia coli and } \\
\text { Salmonella spp. isolates from fresh produce and } \\
\text { the impact to food safety. }\end{array}$ & 2017 & tet $A$, tet $B$, tet $C$ & [41] \\
\hline 21 & Vuthy et al. & $\begin{array}{c}\text { Antibiotic susceptibility and molecular } \\
\text { characterization of resistance genes among } \\
\text { Escherichia coli and among Salmonella subsp. in } \\
\text { chicken food chains. }\end{array}$ & 2017 & tet $A$, tet $B$, sul 1, sul 2 & [58] \\
\hline 22 & Xu et al. & $\begin{array}{l}\text { Development and evaluation of a Luminex } \\
\text { xTAG assay for sulfonamide resistance genes in } \\
\text { Escherichia coli and Salmonella isolates }\end{array}$ & 2019 & sul1, sul2, sul3, sul4 & [10] \\
\hline
\end{tabular}


Table 1. Cont.

\begin{tabular}{|c|c|c|c|c|c|}
\hline Studies & Authors & Title & Year & Genes Searched & Reference \\
\hline 23 & Zhu et al. & $\begin{array}{l}\text { Antimicrobial resistance and resistance genes in } \\
\text { Salmonella strains isolated from broiler chickens } \\
\text { along the slaughtering process in China }\end{array}$ & 2017 & $\begin{array}{l}\text { tet } A, \text { tet } B, \text { tet } C, \text { tet } G, \\
\text { sul1, sul } 2, \text { sul3 }\end{array}$ & [43] \\
\hline 24 & Zhu et al. & $\begin{array}{l}\text { Surveillance study of the prevalence and } \\
\text { antimicrobial resistance of Salmonella in pork } \\
\text { from open markets in Xuzhou, China }\end{array}$ & 2019 & tet $A$, tet $B$, sul1, sul2 & [59] \\
\hline 25 & Zishiri et al. & $\begin{array}{l}\text { Prevalence of virulence and antimicrobial } \\
\text { resistance genes in Salmonella spp. isolated from } \\
\text { commercial chickens and human clinical isolates } \\
\text { from South Africa and Brazil }\end{array}$ & 2016 & tet $A$, tet $B$, sul1, sul2 & [42] \\
\hline
\end{tabular}

The percentage of tetracycline-resistant Salmonella spp. strains in relation to the total of Salmonella strains isolated in the studies varied from 25 to $100 \%$ (average of tetracyclineresistant isolates $=71.1 \%$ ) (Table 2). Similarly, Maka et al. [28] reported tetracycline resistance frequencies among Salmonella spp. strains isolated from various meats (pork, chicken, turkey, beef, and fish) were often $50.0 \%$ or higher (50-76\%) in Brazil, Canada, Iran, India, Turkey, UK and Vietnam. A high frequency of Salmonella bacteria showed resistance to tetracycline (62-69\%) in some studies [60-62].

Table 2. Prevalence of tetracycline and sulfonamide resistance in relation to the total number of Salmonella isolates.

\begin{tabular}{|c|c|c|c|c|c|}
\hline Studies & $\begin{array}{c}\text { No. of } \\
\text { Salmonella Isolates }\end{array}$ & $\begin{array}{c}\text { Tetracycline- } \\
\text { Resistant Isolates } \\
\text { n ( } \%)\end{array}$ & $\begin{array}{l}\text { Isolates with tet } \\
\text { Genes n (\%) }\end{array}$ & $\begin{array}{c}\text { Sulfonamide- } \\
\text { Resistant Isolates } \\
\text { n ( } \%)\end{array}$ & $\begin{array}{c}\text { Isolates with sul } \\
\text { Genes n (\%) }\end{array}$ \\
\hline Aslam et al. 2012 [45] & 110 & $54(49.0 \%)$ & $45(40.9 \%)$ & $9(8.0 \%)$ & $9(8.0 \%)$ \\
\hline Dahshan et al. 2010 [46] & 44 & $44(100 \%)$ & $10(22.7 \%)$ & $44(100 \%)$ & $8(18.2 \%)$ \\
\hline Deng et al. 2017 [38] & 152 & $123(80.9 \%)$ & $123(80.9 \%)$ & $98(64.5 \%)$ & $60(39.5 \%)$ \\
\hline Dessie et al. 2013 [27] & 33 & $23(69.7 \%)$ & $8(24.2 \%)$ & $31(93.9 \%)$ & $26(78.8 \%)$ \\
\hline El-Sharkawy et al. 2017 [47] & 67 & $61(91.0 \%)$ & $58(86.6 \%)$ & $3(5.2 \%)$ & $58(86.6 \%)$ \\
\hline Hsu et al. 2014 [48] & 54 & $18(33.3 \%)$ & $14(26.0 \%)$ & $20(37.0 \%)$ & $16(29.6 \%)$ \\
\hline Igbinosa 2015 [44] & 150 & $73(48.7 \%)$ & 0 & $99(66.0 \%)$ & $*$ \\
\hline Iwu et al. 2016 [39] & 48 & $48(100 \%)$ & $30(61.0 \%)$ & $36(75.0 \%)$ & * \\
\hline Khoshbakht et al. 2018 [49] & 60 & $60(100 \%)$ & $6(10.0 \%)$ & * & * \\
\hline Kozak et al. 2009 [50] & 234 & * & $*$ & * & $210(89.7 \%)$ \\
\hline Lapierre et al. 2010 [51] & 69 & $65(94.2 \%)$ & $49(71.0 \%)$ & $19(27.5 \%)$ & $*$ \\
\hline Lopes et al. 2015 [52] & 225 & $122(54.5 \%)$ & $73(32.5 \%)$ & $89(39.6 \%)$ & $65(28.9 \%)$ \\
\hline Maka et al. 2015 [7] & 84 & $*$ & $*$ & $84(100 \%)$ & $76(90.5 \%)$ \\
\hline Marquéz et al. 2017 [53] & 39 & $19(47.6 \%)$ & $6(14.3 \%)$ & $15(38.1 \%)$ & $4(9.5 \%)$ \\
\hline Mthembu et al. 2019 [54] & 106 & $67(63.0 \%)$ & $25(26.0 \%)$ & $41(38.0 \%)$ & $22(21.0 \%)$ \\
\hline Sadiq et al. 2017 [40] & 4 & $3(75.0 \%)$ & $3(75.0 \%)$ & $*$ & $*$ \\
\hline Soyer et al. 2013 [55] & 336 & $296(88.0 \%)$ & $44(13.1 \%)$ & $282(84.0 \%)$ & $49(14.6 \%)$ \\
\hline Tajbakhsh et al. 2012 [56] & 71 & $18(25.0 \%)$ & $34(48.0 \%)$ & $21(30.0 \%)$ & $23(32.0 \%)$ \\
\hline Thai et al. 2012 [57] & 97 & $47(48.5 \%)$ & $40(41.2 \%)$ & $55(56.7 \%)$ & $52(53.6 \%)$ \\
\hline Vital et al. 2017 [41] & 24 & $16(66.7 \%)$ & $21(87.5 \%)$ & * & $*$ \\
\hline Vuthy et al. 2017 [58] & 181 & $157(86.7 \%)$ & $117(64.6 \%)$ & $156(86.2 \%)$ & $78(43.1 \%)$ \\
\hline Xu et al. 2019 [10] & 18 & * & * & $13(72.2 \%)$ & $14(77.8 \%)$ \\
\hline Zhu et al. 2017 [43] & 189 & $98(51.9 \%)$ & $84(44.4 \%)$ & $91(48.1 \%)$ & $89(47.1 \%)$ \\
\hline Zhu et al. 2019 [59] & 155 & $143(92.0 \%)$ & $32(20.6 \%)$ & $81(52.2 \%)$ & $29(18.7 \%)$ \\
\hline Zishiri et al. 2016 [42] & 146 & $136(93.0 \%)$ & $128(87.7 \%)$ & $123(84.0 \%)$ & $125(85.6 \%)$ \\
\hline
\end{tabular}

* Antimicrobials were not tested, or genes were not searched in the study.

Romero-Barrios et al. [63] isolated 1495 Salmonella strains in raw chicken products processed in slaughterhouses inspected by the Canadian federal government and sold at retail, and of these 642 (42.9\%) strains showed resistance to tetracycline. Lopes et al. [52] isolated a total of 225 Salmonella strains from feed, pigs, and carcasses in Brazil and resistance was found most frequently to tetracycline (54.5\%). Wang et al. [64] analyzed a total of 11.447 isolates of $S$. Typhimurium recovered from humans $(n=6381)$, animals $(n=2940)$, 
and retail meats $(\mathrm{n}=2126)$, and tetracycline resistance was around $70 \%$ for Salmonella strains isolated from animals and meats, and around $40 \%$ for strains of human origin.

For sulfonamide, the percentage of resistant isolates in relation to the total of Salmonella strains in the studies varied from 5.2 to $100 \%$ (average of sulfonamide-resistant isolates $=57.4 \%$ ) (Table 2). Other studies also reported high sulfonamide resistance in Salmonella strains [65-69]. $\mathrm{Xu}$ et al. [65] showed high Salmonella resistance to sulfonamide (73.0\%) in the results for antimicrobial resistance profiles of strains isolated from chicken in China. Moe et al. [66] studied the antimicrobial resistance of Salmonella isolated from chicken carcasses in Myanmar and the isolates were most frequently resistant to trimethoprim-sulfamethoxazole (70.3\%) and tetracycline (54.3\%).

Sodagari et al. [68] studied the antimicrobial resistance of Salmonella serotypes isolated from retail chicken meat in Iran and found high antimicrobial resistance rates were against tetracycline (81\%) and sulfamethoxazole-trimethoprim (61.2\%). Zeng et al. [69] determined the antimicrobial resistance of Salmonella in pork, chicken, and duck from retail markets in China, and the highest resistance was to trimethoprim-sulfamethoxazole (94.5\%), followed by tetracycline $(55.4 \%)$.

Voss-Rech et al. [70] conducted a meta-analysis to assess the profile and temporal evolution of the antimicrobial resistance of nontyphoidal Salmonella isolated from poultry and humans in Brazil from 1995 to 2014. In the nontyphoidal isolates of poultry origin, the highest levels of antimicrobial resistance were verified for sulfonamides (44.3\%), nalidixic acid $(42.5 \%)$, and tetracycline $(35.5 \%)$. In the human-origin isolates, the resistance occurred mainly for sulfonamides $(46.4 \%)$, tetracycline $(36.9 \%)$, and ampicillin $(23.6 \%)$. Vaez et al. [71] also conducted a meta-analysis to determine the antimicrobial resistance profiles of Salmonella serotypes isolated from animals in Iran and isolates were mostly resistant against nalidixic acid (67\%), then tetracycline $(66.9 \%)$, followed by trimethoprim/sulfamethoxazole $(41.6 \%)$.

The most searched tetracycline-resistance genes were: tet $A$ with 21 studies $(94.5 \%)$, tet $B$ with 19 studies (86.4\%), tetC with 11 studies (50.0\%) and tet $G$ with 10 studies $(45.5 \%)$, while the least searched genes were tet $D$ with 3 studies (13.6\%) and tet $E$ with 2 studies (9.1\%) (Figure 1). The tet $A$ gene was found in all 21 studies that searched for this gene, and its presence in Salmonella spp. strains varied from 8.0 to $87.5 \%$ (average of tet $A$ gene in isolates $=47.7 \%$ ). The tet $B$ gene was found in 12 studies and its presence in Salmonella spp. strains varied from 0 to $75.0 \%$ (average of $t e t B$ gene in isolates $=28.3 \%$ ). The tet $C$ gene was present in 6 studies and its presence in Salmonella spp. strains varied from 0 to $86.6 \%$ (average of tetC gene in isolates $=19.9 \%$ ). The tet $G$ gene was found in 9 studies and its presence in Salmonella spp. strains varied from 0 to $26.0 \%$ (average of tet $G$ gene in isolates $=8.4 \%$ ). The tet $E$ and tetD genes were not present in Salmonella spp. isolates (Table 3).

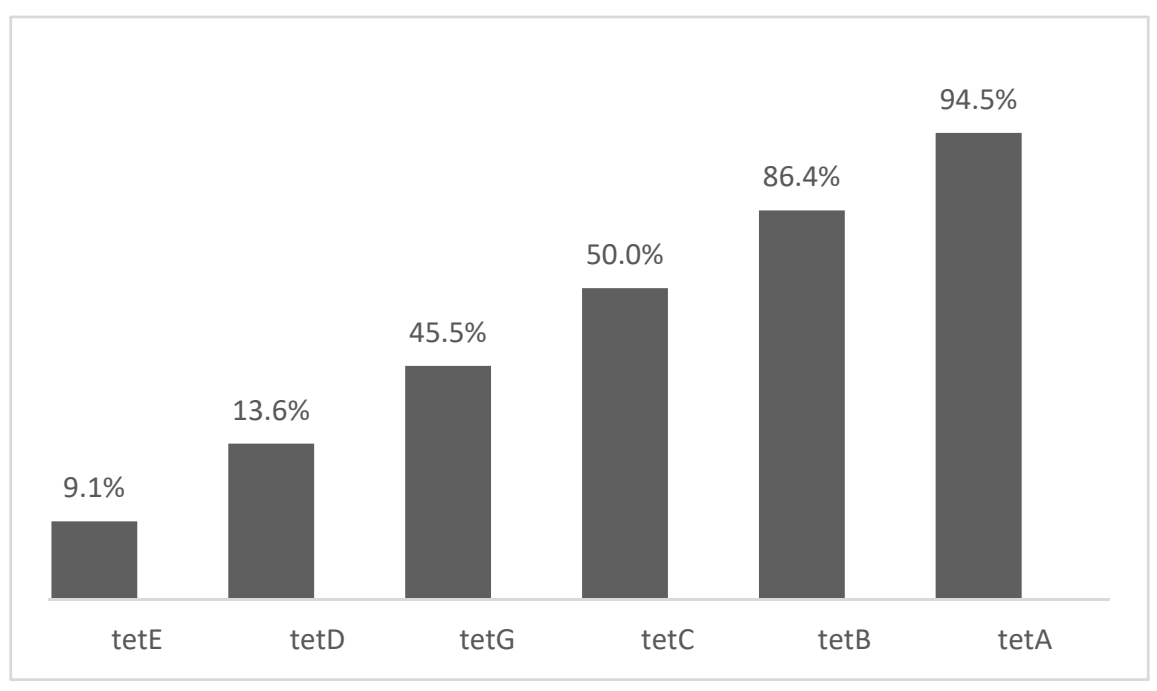

Figure 1. Percentage of studies that searched for tetracycline resistance genes. 
Table 3. Distribution of tetracycline and sulfonamide resistance genes in relation to Salmonella isolates with.

\begin{tabular}{|c|c|c|c|c|c|c|c|c|c|c|c|}
\hline \multirow{2}{*}{ Studies } & \multirow{2}{*}{$\begin{array}{l}\text { Salmonella } \\
\text { Isolates (n) }\end{array}$} & \multicolumn{10}{|c|}{ tet and sul Genes in Salmonella Isolates n (\%) } \\
\hline & & tet $A$ & tetB & tetC & tetD & tetE & tet $G$ & sul1 & sul2 & sul3 & sul4 \\
\hline $\begin{array}{l}\text { Aslam et al. } \\
2012 \text { [45] }\end{array}$ & $\begin{array}{l}45 \text { tet } \\
9 \text { sul }\end{array}$ & $31(68.7 \%)$ & $14(31.2 \%)$ & $0 \%$ & * & * & * & $5(55.6 \%)$ & $3(33.3 \%)$ & $1(11.2 \%)$ & * \\
\hline $\begin{array}{l}\text { Dahshan et al. } \\
2010 \text { [46] }\end{array}$ & $\begin{array}{l}10 \mathrm{tet} \\
10 \mathrm{sul}\end{array}$ & $6(60.0 \%)$ & $2(20.0 \%)$ & * & * & * & $2(20.0 \%)$ & $8(80.0 \%)$ & * & * & * \\
\hline $\begin{array}{l}\text { Deng et al. } \\
2017 \text { [38] }\end{array}$ & $\begin{array}{l}123 \mathrm{tet} \\
60 \mathrm{sul}\end{array}$ & $54(44.7 \%)$ & $11(9.0 \%)$ & $42(34.1 \%)$ & * & * & $27(21.9 \%)$ & $20(33.3 \%)$ & $20(33.3 \%)$ & $20(33.3 \%)$ & * \\
\hline $\begin{array}{l}\text { Dessie et al. } \\
2013 \text { [27] }\end{array}$ & $\begin{array}{l}33 \text { tet } \\
33 \text { sul }\end{array}$ & $8(24.2 \%)$ & $0 \%$ & $0 \%$ & $0 \%$ & $0 \%$ & $0 \%$ & $0 \%$ & $26(78.8 \%)$ & * & * \\
\hline $\begin{array}{l}\text { El-Sharkawy } \\
\text { et al. } 2017 \text { [47] }\end{array}$ & $\begin{array}{l}67 \mathrm{tet} \\
67 \mathrm{sul}\end{array}$ & $55(82.0 \%)$ & $0 \%$ & $58(86.6 \%)$ & $*$ & * & $*$ & $34(50.7 \%)$ & $0 \%$ & $57(85.1 \%)$ & * \\
\hline $\begin{array}{l}\text { Hsu et al. } \\
2014 \text { [48] }\end{array}$ & $\begin{array}{l}54 \text { tet } \\
54 \mathrm{sul}\end{array}$ & $13(24.1 \%)$ & $1(1.9 \%)$ & * & * & * & * & $16(29.6 \%)$ & * & * & * \\
\hline $\begin{array}{l}\text { Igbinosa } \\
2015 \text { [44] }\end{array}$ & 73 tet & $*$ & * & $0 \%$ & * & * & * & * & * & * & * \\
\hline $\begin{array}{l}\text { Iwu et al. } \\
2016 \text { [39] }\end{array}$ & 48 tet & $30(61.0 \%)$ & * & * & * & * & * & * & * & * & * \\
\hline $\begin{array}{l}\text { Khoshbakht } \\
\text { et al. } 2018 \text { [49] }\end{array}$ & 60 tet & $6(10.0 \%)$ & $0 \%$ & $3(5.0 \%)$ & * & * & $0 \%$ & * & * & * & * \\
\hline $\begin{array}{c}\text { Kozak et al. } \\
2009 \text { [50] }\end{array}$ & $234 \mathrm{sul}$ & * & * & * & * & * & * & $180(76.9 \%)$ & $25(10.7 \%)$ & $5(2.1 \%)$ & * \\
\hline $\begin{array}{l}\text { Lapierre et al. } \\
2010[51]\end{array}$ & 65 tet & $10(15.4 \%)$ & $39(60.0 \%)$ & * & * & * & $0 \%$ & * & * & * & * \\
\hline $\begin{array}{l}\text { Lopes et al. } \\
2015 \text { [52] }\end{array}$ & $\begin{array}{l}91 \mathrm{tet} \\
91 \mathrm{sul}\end{array}$ & $61(67.0 \%)$ & $30(32.9 \%)$ & * & $*$ & * & * & $47(51.6 \%)$ & $14(15.4 \%)$ & $11(12.1 \%)$ & * \\
\hline $\begin{array}{l}\text { Maka et al. } \\
2015 \text { [7] }\end{array}$ & 84 sul & * & * & * & * & * & * & $37(44.0 \%)$ & $39(46.4 \%)$ & 0 & * \\
\hline $\begin{array}{l}\text { Marquéz et al. } \\
2017 \text { [53] }\end{array}$ & $\begin{array}{l}39 \text { tet } \\
39 \text { sul }\end{array}$ & $4(9.5 \%)$ & $0 \%$ & $2(4.8 \%)$ & $0 \%$ & $0 \%$ & $0 \%$ & $4(9.5 \%)$ & $*$ & * & * \\
\hline $\begin{array}{l}\text { Mthembu et al. } \\
2019 \text { [54] }\end{array}$ & $\begin{array}{l}106 \mathrm{tet} \\
106 \mathrm{sul}\end{array}$ & $9(8.0 \%)$ & * & $19(18.0 \%)$ & $*$ & * & * & $22(21.0 \%)$ & * & * & * \\
\hline $\begin{array}{l}\text { Sadiq et al. } \\
2017 \text { [40] }\end{array}$ & 4 tet & $2(50.0 \%)$ & $3(75.0 \%)$ & * & * & * & * & * & * & * & * \\
\hline $\begin{array}{l}\text { Soyer et al. } \\
2013 \text { [55] }\end{array}$ & $\begin{array}{l}48 \text { tet } \\
48 \text { sul }\end{array}$ & $36(75.0 \%)$ & $3(6.3 \%)$ & * & * & * & $5(10.4 \%)$ & $23(47.9 \%)$ & $26(54.2 \%)$ & $*$ & * \\
\hline $\begin{array}{l}\text { Tajbakhsh et al. } \\
2012 \text { [56] }\end{array}$ & $\begin{array}{l}71 \mathrm{tet} \\
71 \mathrm{sul}\end{array}$ & $20(28.0 \%)$ & $10(14.0 \%)$ & $0 \%$ & $0 \%$ & * & $4(6.0 \%)$ & $23(32.0 \%)$ & * & * & * \\
\hline $\begin{array}{l}\text { Thai et al. } \\
2012 \text { [57] }\end{array}$ & $\begin{array}{l}50 \mathrm{tet} \\
58 \mathrm{sul}\end{array}$ & $37(74.0 \%)$ & $3(6.0 \%)$ & * & * & * & $13(26.0 \%)$ & $52(89.7 \%)$ & * & * & * \\
\hline $\begin{array}{l}\text { Vital et al. } \\
2017 \text { [41] }\end{array}$ & 24 tet & $21(87.5 \%)$ & $0 \%$ & $0 \%$ & * & * & * & * & * & * & * \\
\hline $\begin{array}{l}\text { Vuthy et al. } \\
2017 \text { [58] }\end{array}$ & $\begin{array}{l}157 \mathrm{tet} \\
156 \mathrm{sul}\end{array}$ & 117 (64.6\%) & $0 \%$ & * & * & * & * & $39(25.0 \%)$ & $38(24.3 \%)$ & * & * \\
\hline $\begin{array}{l}\text { Xu et al. } \\
2019 \text { [10] }\end{array}$ & $18 \mathrm{sul}$ & * & * & * & * & * & * & $10(55.6 \%)$ & $13(72.2 \%)$ & $5(27.8 \%)$ & $1(5.6 \%)$ \\
\hline $\begin{array}{l}\text { Zhu et al. } \\
2017 \text { [43] }\end{array}$ & $\begin{array}{l}98 \text { tet } \\
91 \text { sul }\end{array}$ & $23(23.5 \%)$ & $49(50.0 \%)$ & $70(71.4 \%)$ & * & * & $0 \%$ & $43(50.0 \%)$ & $89(97.8 \%)$ & $43(50.0 \%)$ & * \\
\hline $\begin{array}{l}\text { Zhu et al. } \\
2019 \text { [59] }\end{array}$ & $\begin{array}{l}29 \text { sul } \\
45 \text { tet }\end{array}$ & $32(71.1 \%)$ & $0 \%$ & * & * & * & * & $18(62.1 \%)$ & $18(62.1 \%)$ & * & * \\
\hline $\begin{array}{l}\text { Zishiri et al. } \\
2016 \text { [42] }\end{array}$ & $\begin{array}{l}146 \text { tet } \\
146 \mathrm{sul}\end{array}$ & 79 (54.1\%) & 49 (33.6\%) & * & * & * & * & $76(52.1 \%)$ & $74(50.7 \%)$ & * & * \\
\hline
\end{tabular}

* genes were not searched in the study.

Zhang et al. [72] reported that among 105 tetracycline-resistant Salmonella, tet $A$ gene was most frequently detected $(80.9 \%)$, and only $4.8 \%$ of isolates harbored tet $B$ gene. The authors [73] reported that tet $A$ and tet $B$ genes are widely detected in fecal coliforms from rivers and animal sources. Matielo et al. [73] determined the antimicrobial resistance in Salmonella enterica strains isolated from Brazilian poultry production, and the genes tet $A$, tet $B$ and tet $C$ were detected in $60 \%, 5 \%$ and $5 \%$ of these isolates, respectively. SanchezMaldonado et al. [74] searched the antimicrobial resistance of Salmonella isolated from two 
pork processing plants in Canada, and the most prevalent genes were tet $B$, found in $21.3 \%$ of isolates and tet $A$, found in $12.6 \%$ of isolates.

According to Roberts and Schwarz [25], the tetB gene is specific for Gram-negative aerobic and facultative anaerobic bacteria, being present in $33 \mathrm{Gram}$-negative genera. If other aerobic and facultative anaerobic Gram-negative genes are of interest, the tet $A$ gene is the next most common, being present in $23 \mathrm{Gram}$-negative genera. The tet genes are the most regularly found in Enterobacteriaceae [61]. The most common tetracycline resistance mechanism is antibiotic efflux pumps, in which tet genes encode the membrane-associated efflux proteins, which exchange a proton for a tetracycline-cation complex against a concentration gradient, exporting the drug to outside bacterial cells. These genes are generally associated with plasmids, transposons, or both and are often conjugative $[2,3,28]$.

Tet genes belong to classes A, B, C, D and G are placed in the same group due to amino acid sequence similarity. The tetracycline resistance proteins in this group have from $41 \%$ to $78 \%$ amino acid identity [75]. Efflux of tetracyclines predominantly occurs via proteins that are members of the major facilitator superfamily group of integral membrane transporters. These efflux pumps are integral membrane proteins that span the lipid bilayer of the inner cell membrane. Based on homology to other known transporters, the membrane-spanning regions of the protein are predicted to be helical. The structure-function predicts a waterfilled channel surrounded by six transmembrane helices. The tetracycline is predicted to pass through this channel and is exchanged for $\mathrm{H}^{+}$. It is this vectorial flow of protons through the channel, down the $\mathrm{pH}$ gradient, which provides the energy required to pump the antibiotic from the cell [76].

The most searched sulfonamide-resistance genes were: sul1 with 19 studies $(82.6 \%)$, sul2 with 13 studies (56.5\%), while the least searched genes were sul3 with 7 studies (30.4\%), and sul4 with 1 study (4.3\%) (Figure 2). The sul1 gene was found in 18 of 19 studies that searched for this gene, and its presence in Salmonella spp. strains varied from 0 to $89.7 \%$ (average of sul1 gene in isolates $=45.6 \%$ ). The sul2 gene was found in 12 studies and its presence in Salmonella spp. strains varied from 0 to $97.8 \%$ (average of sul2 gene in isolates $=44.5 \%$ ). The sul3 gene was found in six studies and its presence in Salmonella spp. strains varied from 0 to $85.1 \%$ (average of sul3 gene in isolates $=31.6 \%$ ) (Table 3 ).

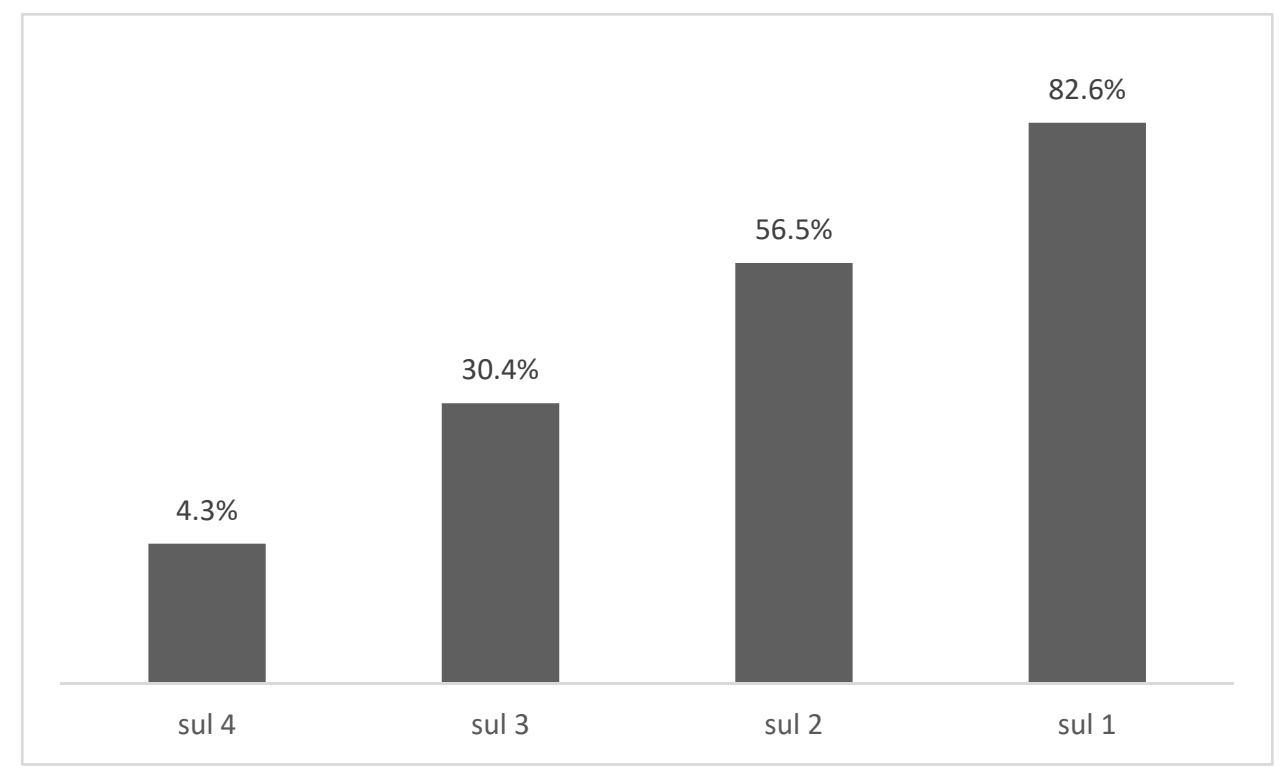

Figure 2. Percentage of studies that searched for sulfonamide resistance genes.

Ma et al. [77] determined the antimicrobial resistance of Salmonella isolated from chickens and pigs on farms, abattoirs, and markets in Sichuan Province, China and among 74 strains carrying sulfonamides resistance gene, sul1 was the most common (43.2\%), followed by sul2 (55.4\%) and sul3 (25.7\%). Sanchez-Maldonado et al. [74] searched the 
antimicrobial resistance of Salmonella isolated from two pork processing plants in Alberta, Canada, and the most prevalent genes among those screened were sul2, found in $21.3 \%$ of isolates and sul1, found $18.1 \%$ of isolates. Zhu et al. [59] reported that the presence of the genes sul1 and sul2 was equal in Salmonella strains isolated from pork meat resistant to trimethoprim/sulfamethoxazole in China.

Zhu et al. [43] reported that among 91 sulfonamide-resistant isolates, $97.8 \%(n=89)$ harbored at least one of the genes studied (sul1, sul2 or sul3). The sul2 gene had the highest occurrence $(97.8 \%, \mathrm{n}=89)$ compared to the sul1 and sul3 genes (both with $50.5 \%, \mathrm{n}=46$ ). According to Maka et al. [7] dissemination of sul1 and sul2 genes among Salmonella spp. is reported more often than sul3 gene. Xu et al. [10] also reported that sul1 and sul2 genes are often found at roughly the same frequency among sulfonamide resistant Gram-negative isolates. According to Machado et al. [78] the presence of sul genes continues to be reported in surveys of environmental bacteria with sul2 dominating but closely followed by sul1, and sul3 is still rarer.

The sul genes are found in plasmids and are associated with ubiquitous and longknown sulfonamide resistance Gram-negative bacteria [10]. The sull gene is typically found in class 1 integrons and linked to other resistance genes, whereas sul2 gene is usually associated with small multicopy plasmids or large transmissible multiresistance plasmids [8,19]. The sul3 gene was identified in conjugative plasmids in E. coli, while the sul4 gene was identified in a systematic prospection of class 1 integron genes in Indian river sediments [8].

According to Perreten and Boerlin [31] sul1 and sul2 from E. coli share 57\% of DNA identity and sul3 revealed amino acid identities of $50.4 \%$ overall to sul 2 from Salmonella enterica subsp. enterica plasmid, and $40.9 \%$ to sul1 from E. coli plasmid. Based on amino acid homology and phenotype, sul3 was considered a new sulfonamide-resistant DHPS. According to Razavi et al. [32] sul4 was identified with 31-33\% identity to known mobile sulfonamide resistance genes (sul1, sul2 and sul3). Based on its ability to provide sulfonamide resistance, its mobile character, as demonstrated by its presence in integrons, and the homology to previously known sulfonamide resistance genes, the name sul4 was proposed. Structural prediction of sul1, sul2, sul3 and sul4 indicates strong overall similarities. The structure of the genes contains the binding sites for 7,8-dihydropterin pyrophosphate (DHPP), para-aminobenzoic acid (PABA), and sulfonamide. After DHPP has bound deep in the structure, sulfonamide binds near the surface of the protein. Thus, sulfonamide binding is affected by changes near the surface of DHPS [32].

The genes sul1, sul2, sul3 and sul4 can spread among bacteria of the same or different species by conjugation or transformation, thereby disseminating resistance genes $[10,19]$. Some studies about sulfonamide resistant isolates where none of these sul genes are detected have appeared in the literature, but so far, no other plasmid sulfonamide resistance gene has been reported [78,79].

Deekshit et al. [80] found that the tetA gene in strains of Salmonella spp. isolated from seafood in India was located on a plasmid and this gene was identical to tet $A$ detected in other bacterial species including Escherichia coli and Vibrio cholerae. According to Vital et al. [41], large conjugative resistance plasmids have been detected in Salmonella food isolates from several countries. Conjugative plasmids can transfer several resistance genes between different bacterial species, and the presence of multiple antibiotic resistance genes facilitates their host survival despite intense antibiotic selection [25].

Selected tet genes are part of multiresistance elements, such as the integrative and mobilizable Salmonella genomic island 1. The majority of the tetracycline-resistance efflux genes have been linked to other antibiotic-resistance genes. These tet genes have been identified in environmental, animal and aquaculture-associated bacteria [81]. Hsu et al. [48] reported that high rates of bacterial resistance to antibiotics such as tetracycline are associated with the intensive use of these drugs in veterinary medicine. Hence, the emergence of resistant bacteria in the food chain has been a cause of great concern, even with the decline of tetracyclines use in clinical treatment $[82,83]$. 
Adesiji et al. [84] detected tet-resistant genes in tet-susceptible Salmonella isolates. The results show that some antimicrobial-resistant genes are silent in bacteria in vitro and indicate that these silent genes can turn on in vivo under selective antibiotic pressure or spread to other bacteria. These results reinforce the importance of determining tet and sul genes in addition to antimicrobial susceptibility tests. Wang et al. [85] also reported some silent or unexpressed sul1 and sul3 genes detected in the isolates of soils, which could be horizontally transferred or expressed under other conditions.

Table 4 presents the primer sequences and PCR conditions used to amplify resistance genes in the studies. The primer sequences used to amplify tetracycline and sulfonamide resistance genes in the studies were a vital inclusion criterion, as designing appropriate primers is essential to a successful PCR experiment outcome [86].

Table 4. Primer sequences and PCR conditions used for the amplification of tetracycline and sulfonamide resistance genes.

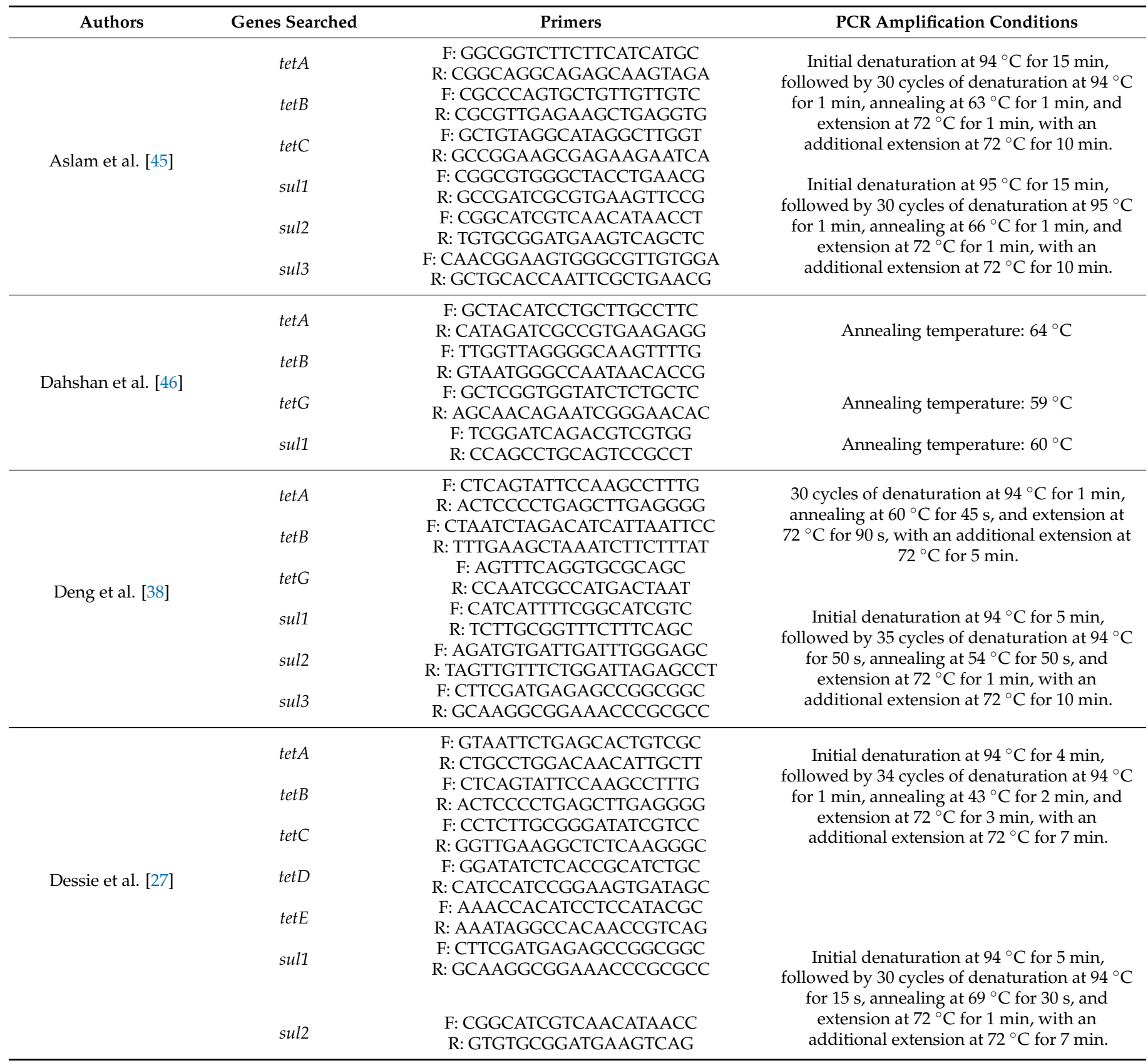


Table 4. Cont.

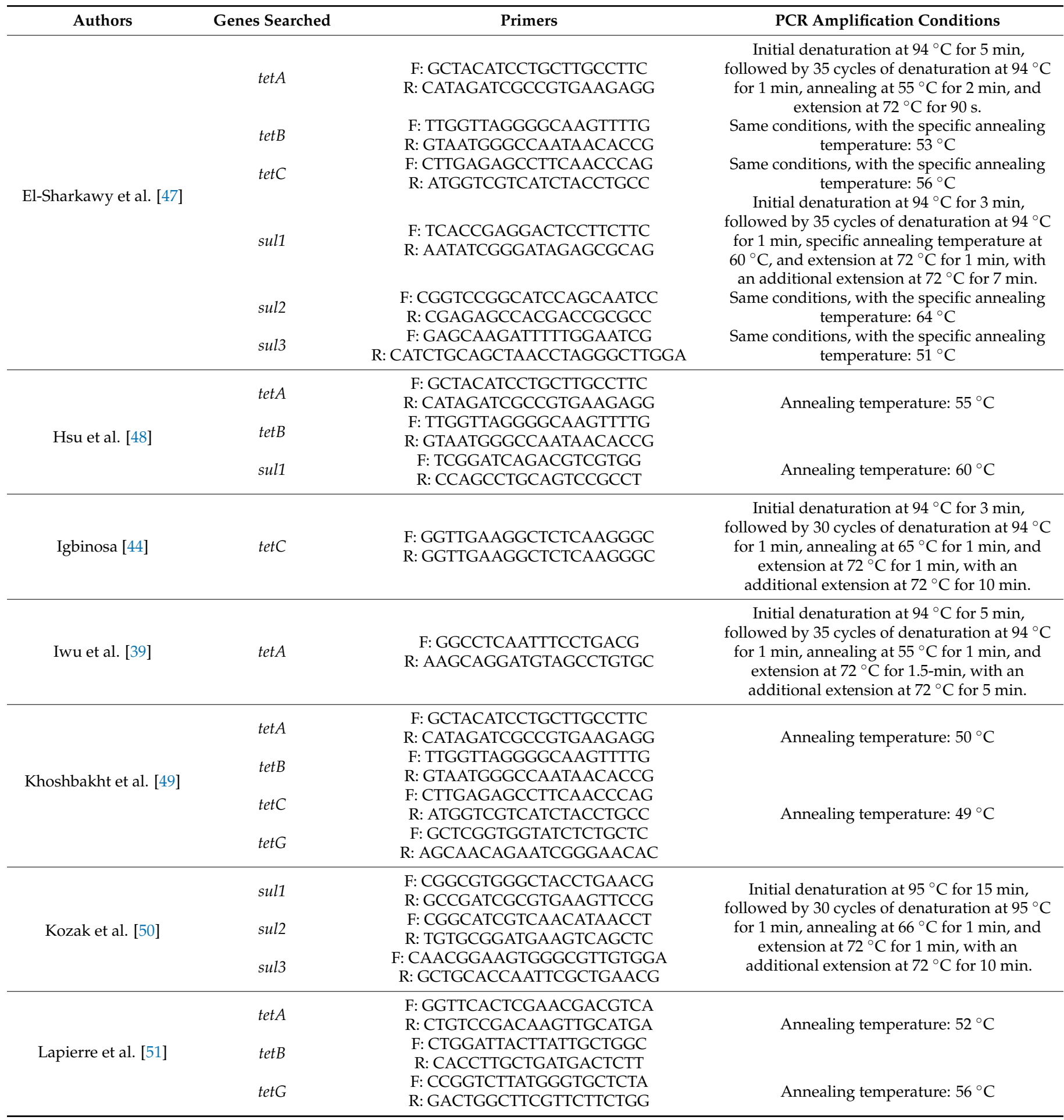


Table 4. Cont.

\begin{tabular}{|c|c|c|c|}
\hline Authors & Genes Searched & Primers & PCR Amplification Conditions \\
\hline \multirow{13}{*}{ Lopes et al. [52] } & & F: GTAATTCTGAGCACTGT & \multirow{6}{*}{$\begin{array}{l}\text { Initial denaturation at } 94^{\circ} \mathrm{C} \text { for } 4 \mathrm{~min}, \\
\text { followed by } 34 \text { cycles of denaturation at } 94{ }^{\circ} \mathrm{C} \\
\text { for } 1 \text { min, annealing at } 43^{\circ} \mathrm{C} \text { for } 2 \text { min, and } \\
\text { extension at } 72^{\circ} \mathrm{C} \text { for } 3 \mathrm{~min} \text {, with an } \\
\text { additional extension at } 72{ }^{\circ} \mathrm{C} \text { for } 7 \mathrm{~min} \text {. }\end{array}$} \\
\hline & tet $A$ & R: CCTGGACAACATTGCTT & \\
\hline & \multirow{2}{*}{ tet $B$} & F: ACGTTACTCGATGCCAT & \\
\hline & & R: AGCACTTGTCTCCTGTT & \\
\hline & tet $G$ & F: CTGCTGATCGTGGGTCT & \\
\hline & \multirow{4}{*}{ sul1 } & R: TTGCGAATGGTCTGCGT & \\
\hline & & & \multirow{7}{*}{$\begin{array}{l}\text { Initial denaturation at } 94^{\circ} \mathrm{C} \text { for } 2 \mathrm{~min} \text {, } \\
\text { followed by } 30 \text { cycles of denaturation at } 94{ }^{\circ} \mathrm{C} \\
\text { for } 1 \mathrm{~min} \text {, annealing at } 51{ }^{\circ} \mathrm{C} \text { for } 1 \mathrm{~min} \text {, and } \\
\text { extension at } 72{ }^{\circ} \mathrm{C} \text { for } 1 \mathrm{~min} \text {, with an } \\
\text { additional extension at } 72^{\circ} \mathrm{C} \text { for } 7 \text { min. } \\
\text { Same conditions, with the specific annealing } \\
\text { temperature of } 64^{\circ} \mathrm{C} \\
\text { Same conditions, with the specific annealing } \\
\text { temperature of } 51^{\circ} \mathrm{C}\end{array}$} \\
\hline & & F: ATGGTGACGGTGTTCGGCATTCTGA & \\
\hline & & R: CTAGGCATGATCTAACCCTCGGTCT & \\
\hline & & F: ACAGTTTCTCCGATGGAGGCC & \\
\hline & SULL & R: CTCGTGTGTGCGGATGAAGTC & \\
\hline & sul3 & F: GAGCAAGATTTTTGGAATCG & \\
\hline & & R: CATCTGCAGCTAACCTAGGGCTTTGGA & \\
\hline \multirow{5}{*}{ Maka et al. [7] } & \multirow{2}{*}{ sul1 } & F: CGGCGTGGGCTACCTGAACG & \multirow{5}{*}{$\begin{array}{l}\text { Initial denaturation at } 94^{\circ} \mathrm{C} \text { for } 5 \mathrm{~min}, \\
\text { followed by } 30 \text { cycles of denaturation at } 94{ }^{\circ} \mathrm{C} \\
\text { for } 30 \mathrm{~s} \text {, annealing at } 68^{\circ} \mathrm{C} \text { for } 25 \mathrm{~s} \text {, and } \\
\text { extension at } 72^{\circ} \mathrm{C} \text { for } 1 \mathrm{~min} \text {, with an } \\
\text { additional extension at } 72^{\circ} \mathrm{C} \text { for } 10 \mathrm{~min} \text {. }\end{array}$} \\
\hline & & R: GCCGATCGCGTGAAGTTCCG & \\
\hline & sul2 & F: GCGCTCAAGGCAGATGGCAT & \\
\hline & \multirow[b]{2}{*}{ sul3 } & R: GCGTTTGATACCGGCACCCGT & \\
\hline & & $\begin{array}{l}\text { F: CAGATAAGGCAATTGAGCATGCTCTGC } \\
\text { R: AGAATGATTTCCGTGACACTGCAATCATT }\end{array}$ & \\
\hline \multirow{14}{*}{ Marquéz et al. [53] } & \multirow[b]{2}{*}{$\operatorname{tet} A$} & F: GCTACATCCTGCTTGCCTTC & \multirow{6}{*}{$\begin{array}{l}\text { Initial denaturation at } 94^{\circ} \mathrm{C} \text { for } 5 \mathrm{~min}, \\
\text { followed by } 35 \text { cycles of denaturation at } 94{ }^{\circ} \mathrm{C} \\
\text { for } 1 \text { min, annealing at } 55^{\circ} \mathrm{C} \text { for } 1 \mathrm{~min} \text {, and } \\
\text { extension at } 72^{\circ} \mathrm{C} \text { for } 1-5 \mathrm{~min} \text {. }\end{array}$} \\
\hline & & R: CATAGATCGCCGTGAAGAGG & \\
\hline & \multirow{2}{*}{ tet $B$} & F: TTGGTTAGGGGCAAGTTTTG & \\
\hline & & R: GTAATGGGCCAATAACACCG & \\
\hline & \multirow{2}{*}{ tet $C$} & F: CTTGAGAGCCTTCAACCCAG & \\
\hline & & R: ATGGTCGTCATCTACCTGCC & \\
\hline & \multirow{2}{*}{ tet $D$} & F: AAACCATTACGGCATTCTGC & \\
\hline & & R: GACCGGATACACCATCCATC & \\
\hline & \multirow{2}{*}{ tetE } & F: AAACCACATCCTCCATACGC & \\
\hline & & R: AAATAGGCCACAACCGTCAG & \\
\hline & \multirow{2}{*}{ tet $G$} & F: GCTCGGTGGTATCTCTGCTC & \\
\hline & & R: AGCAACAGAATCGGGAACAC & \\
\hline & \multirow{2}{*}{ sul1 } & F: CTTCGATGAGAGCCGGCGGC & \\
\hline & & R: GCAAGGCGGAAACCCGCGCC & Annealıng temperature: $65^{\circ} \mathrm{C}$ for $30 \mathrm{~s}$ \\
\hline \multirow{8}{*}{ Mthembu et al. [54] } & & & Initial denaturation at $95^{\circ} \mathrm{C}$ for $3 \mathrm{~min}$ \\
\hline & & F: GCTACATCCTGCTTGCСТTC & followed by 30 cycles of denaturation at $95^{\circ} \mathrm{C}$ \\
\hline & tet $A$ & R: CATAGATCGCCGTGAAGAGG & for $30 \mathrm{~s}$, annealing at $52^{\circ} \mathrm{C}$ for $30 \mathrm{~s}$, and \\
\hline & & & additional extension at $72^{\circ} \mathrm{C}$ for $8 \mathrm{~min}$. \\
\hline & $\operatorname{tet} C$ & F: CTTGAGAGCCTTCAACCCAG & Same conditions, with the specific annealing \\
\hline & tetc & R: ATGGTCGTCATCTACCTGCC & temperature: $42{ }^{\circ} \mathrm{C}$ \\
\hline & sul2 & F: CGGCATCGTCAACATAACC & Same conditions, with the specific annealing \\
\hline & SULL & R: GTGTGCGGATGAAGTCAG & temperature: $60^{\circ} \mathrm{C}$ \\
\hline & $\operatorname{tet} A$ & F: GGTTCACTCGAACGACGTCA & \\
\hline & tet $A$ & R: CTGTCCGACAAGTTGCATGA & by 30 cycles of denaturation at $95^{\circ} \mathrm{C}$ for $30 \mathrm{~s}$, \\
\hline Sadiq et al. [40] & & & annealing at $61.1^{\circ} \mathrm{C}$ for $30 \mathrm{~s}$, and extension at \\
\hline & tet $B$ & F: CCTCAGCTTCTCAACGCGTG & $68^{\circ} \mathrm{C}$ for $1 \mathrm{~min}$, with an additional extension \\
\hline & $\operatorname{tet} \mathrm{B}$ & R: GCACCTTGCTGATGACTCT & at $68^{\circ} \mathrm{C}$ for $5 \mathrm{~min}$. \\
\hline & & F: GCGCCTTTCCTTTGGGTTCT & \\
\hline & tet $A$ & R: CCACCCGTTCCACGTTGTTA & \\
\hline & tet $B$ & F: CCCAGTGCTGTTGTTGTCAT & \\
\hline & $\operatorname{tetD}$ & R: CCACCACCAGCCAATAAAAT & \\
\hline Soyer et al. [55] & tet $G$ & F: AGCAGGTCGCTGGACACTAT & \\
\hline 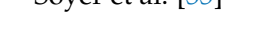 & $\operatorname{tet} \mathrm{G}$ & R: CGCGGTGTTCCACTGAAAAC & followed by 32 to 35 cycles of denaturation at \\
\hline & sul1 & $\begin{array}{l}\text { F: TCACCGAGGACTCCTTCTTC } \\
\text { R: CAGTCCGCCTCAGCAATATC }\end{array}$ & $95^{\circ} \mathrm{C}$ for $30 \mathrm{~s}$, annealing at $55^{\circ} \mathrm{C}$ for $1 \mathrm{~min}$, \\
\hline & & F: CCTGTTTCGTCCGACACAGA & and extension at $72{ }^{\circ} \mathrm{C}$ for $1 \mathrm{~min}$, with an \\
\hline & sul2 & R: GAAGCGCAGCCGCAATTCAT & \\
\hline
\end{tabular}


Table 4. Cont.

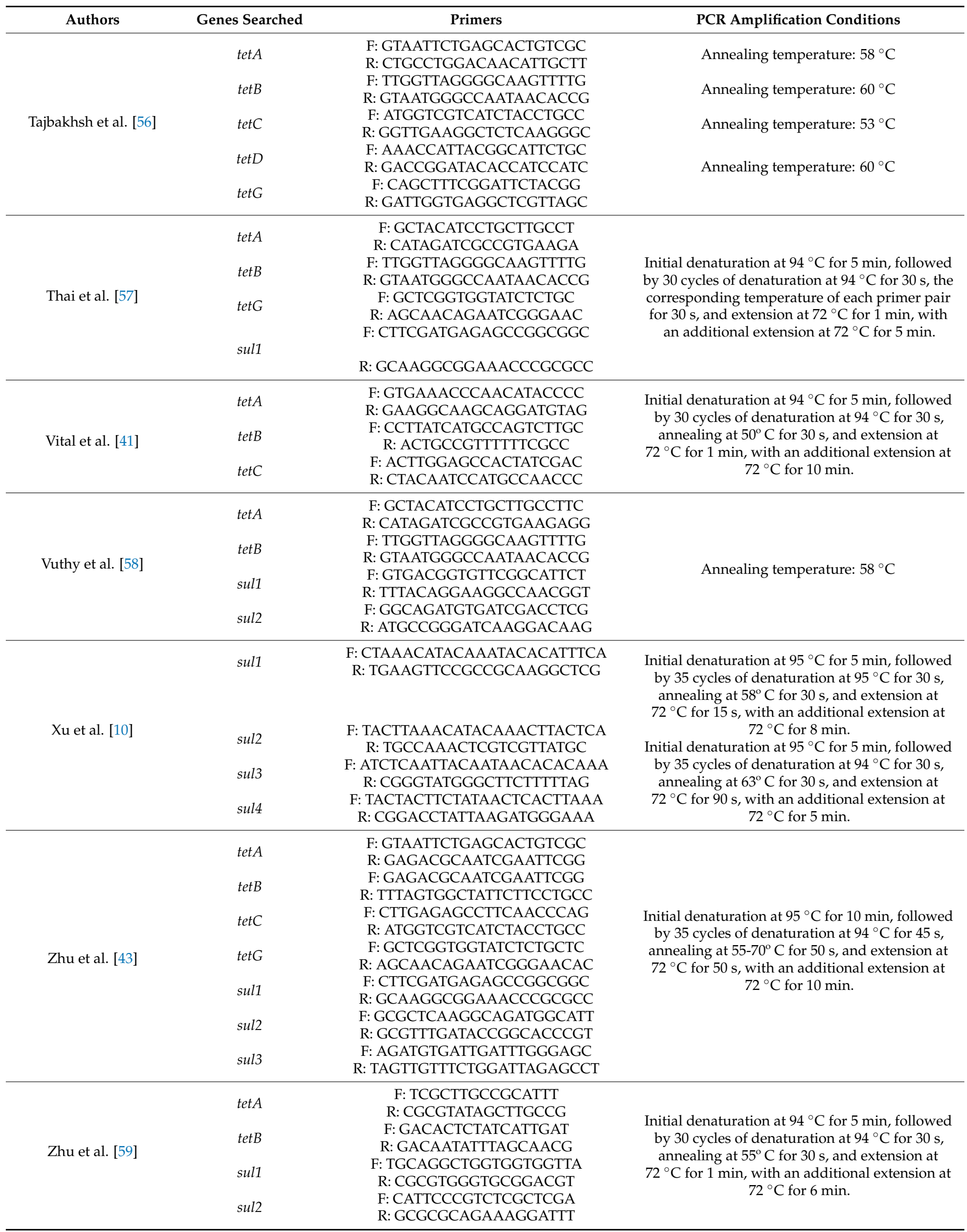


Table 4. Cont.

\begin{tabular}{|c|c|c|c|}
\hline Authors & Genes Searched & Primers & PCR Amplification Conditions \\
\hline Zishiri et al. [42] & $\begin{array}{l}\text { tetB } \\
\text { sul1 } \\
\text { sul2 }\end{array}$ & $\begin{array}{c}\text { F: GCTACATCCTGCTTGCCTT } \\
\text { R: CATAGATCGCCGTGAAGAGG } \\
\text { F: TTGGTTAGGGGCAAGTTTTG } \\
\text { R: GTAATGGGCCAATAACACCG } \\
\text { F: GCGCGGCGTGGGCTACCT } \\
\text { R: GATTTCCGCGACACCGAGACAA } \\
\text { F: CGGCATCGTCAACATAACC } \\
\text { R: GTGTGCGGATGAAGTCAG }\end{array}$ & $\begin{array}{l}\text { Initial denaturation at } 94^{\circ} \mathrm{C} \text { for } 5 \mathrm{~min} \text {, } \\
\text { followed by } 34 \text { cycles of denaturation at } 94{ }^{\circ} \mathrm{C} \\
\text { for } 25 \mathrm{~s} \text {, annealing at } 55^{\circ} \mathrm{C} \text { for } 50 \mathrm{~s} \text {, and } \\
\text { extension at } 72{ }^{\circ} \mathrm{C} \text { for } 50 \mathrm{~s} \text {, with an additional } \\
\text { extension at } 72^{\circ} \mathrm{C} \text { for } 5 \text { min. } \\
\text { Same conditions, with the specific annealing } \\
\text { temperature at } 65^{\circ} \mathrm{C} \text {. }\end{array}$ \\
\hline
\end{tabular}

The target specificity is a critical primer property, and, ideally, a primer pair should only amplify the intended target. Several software tools have been developed to aid the primer design process. The Primer3 program is widely used in designs of the primers, however, it does not analyze the target of the primers specificity, so the user will need additional tools such as the software Primer-BLAST to test for specificity. This software ensures a complete primer-target alignment while being sensitive enough to detect a significant number of primer-target mismatches. Primer-BLAST software can also help design new target-specific primers in one step and check pre-existing specificity of the primers [87].

Another essential factor for the success of the experiment is the optimization of the conditions of the PCR. The choice of the correct thermal cycling conditions is vital to obtain better results in the research and replication of the method. In addition to bringing efficient results and reducing the attempts of the researcher, the optimization of PCR conditions also avoids some common problems, such as the amplifying of non-specific products or the absence of a product in the result [88].

The most frequent samples used in studies to isolate Salmonella spp. strains were: 13 samples from poultry-origin $(52.0 \%)$, followed by 11 samples from swine-origin $(44.0 \%)$ and 7 samples from bovine-origin (28.0\%); while 4 studies used human samples, 2 studies used goat samples, 2 studies used water samples, 1 study used hen eggs, and another study used fresh vegetable samples (Table 5).

Salmonellosis is a significant zoonosis worldwide and is widespread in animals [89,90]. The present review found that the most frequent Salmonella isolates were from poultry and pork meat samples. Chicken meat is a widely consumed product worldwide, and different studies register contamination by Salmonella in this type of food [27,42,43]. Ren et al. [91] reported that the high contamination rates in the supply chain show that chicken products are an important vector of S. enterica. Previous studies have shown that the continuous circulation of $S$. enterica in the broiler supply system poses a potential risk of spreading Salmonella to humans [91-95].

Salmonella contamination in poultry and pigs is often asymptomatic and rarely causes less severe and transient diarrhea. Consumption of contaminated chicken and pork predisposes humans to Salmonella infection $[42,43,96]$. The presence of Salmonella in cattle in some studies $[38,40,55]$ and the possibility of cross-contamination of the carcass in the slaughter of these animals may pose a risk to food safety in the consumption of this type of food [97].

Salmonella ssp. is an etiologic agent often cited as causing foodborne diseases [98,99]. In most cases, salmonellosis is caused by contaminated food products, particularly of animal origins such as poultry, eggs, beef, and pork [44]. The genetic constitution of these bacteria allows them to adapt to various environments and animals, including mammalian and non-mammalian hosts, making them widespread worldwide [82].

The abusive use of tetracycline and sulfonamides associated with the presence of Salmonella in different food sources has promoted the rise of resistant strains $[42,81,99]$. In Brazil, despite the ban on the use of antibiotics as performance enhancers in poultry production [100], tetracyclines have already been widely used as growth promoters. The presence of resistance genes found in this review suggests a remarkable ability of Salmonella spp. to survive in environments where antimicrobial agents are broadly used [42]. 
There is further concern regarding the release of these substances into the environment through hospital and industrial effluents, domestic sewage, and the disposal of expired drugs. Additionally, any resistance in potentially virulent strains of humans and animals can quickly spread, making their circulation in the environment more frequent [101-105].

Table 5. Type of samples used to isolate Salmonella spp.

\begin{tabular}{|c|c|c|}
\hline Studies & Type of Samples & Salmonella spp. Isolates n (\%) \\
\hline Aslam et al. 2012 [45] & $\begin{array}{l}564 \text { meat samples (206 chicken, } 91 \text { turkey, } 134 \text { beef and } \\
133 \text { pork) }\end{array}$ & $\begin{array}{c}210 \text { isolates (183 strains from chicken; } 24 \text { strains from } \\
\text { turkey and } 3 \text { strains from pork) }(37.2 \%)\end{array}$ \\
\hline Dahshan et al. 2010 [46] & 270 pig fecal samples & 44 isolates $(16.3 \%)$ \\
\hline Deng et al. 2017 [38] & 327 meat samples (137 pork, 91chicken and 99 beef) & $\begin{array}{c}252 \text { isolates (175 strains from pork, } 43 \text { strains from } \\
\text { chicken and } 34 \text { strains from beef) }(46.5 \%)\end{array}$ \\
\hline Dessie et al. 2013 [27] & Chicken fecal samples & 33 isolates \\
\hline El-Sharkawy et al. 2017 [47] & $\begin{array}{c}615 \text { samples collected from intestine, liver, and gall } \\
\text { bladder from chickens }\end{array}$ & 67 isolates $(10.9 \%)$ \\
\hline Hsu et al. 2014 [48] & 236 water samples from river sheds & 54 isolates $(22.9 \%)$ \\
\hline Igbinosa 2015 [44] & Cow and goat fecal samples & $\begin{array}{c}250 \text { isolates (182 strains from cow feces and } 68 \text { strains } \\
\text { from goat feces) }\end{array}$ \\
\hline Iwu et al. 2016 [39] & 500 adult pig fecal samples & 48 isolates $(9.6 \%)$ \\
\hline Khoshbakht et al. 2018 [49] & Human and poultry samples & 60 isolates \\
\hline Kozak et al. 2009 [50] & 938 chicken and swine meat samples & $\begin{array}{c}234 \text { isolates (13 strains from chicken and } 221 \text { strains } \\
\text { from swine) }(24.9 \%)\end{array}$ \\
\hline Lapierre et al. 2010 [51] & $\begin{array}{l}580 \text { healthy swine samples ( } 290 \text { fecal samples and } \\
290 \text { lymph node samples) }\end{array}$ & 65 isolates $(11.2 \%)$ \\
\hline Lopes et al. 2015 [52] & 1771 samples from pig feces and carcasses & 225 isolates $(12.7 \%)$ \\
\hline Maka et al. 2015 [7] & Retail meat samples (poultry, pork, and beef) & 84 isolates \\
\hline Marquéz et al. 2017 [53] & 120 hen eggshells & 39 isolates $(32.5 \%)$ \\
\hline Mthembu et al. 2019 [54] & $\begin{array}{c}361 \text { fecal samples (cattle, sheep, goats, pigs, ducks, and } \\
\text { chickens) }\end{array}$ & 106 isolates $(29.4 \%)$ \\
\hline Sadiq et al. 2017 [40] & Beef, poultry, and human samples & $\begin{array}{l}4 \text { isolates ( } 2 \text { strains from human clinical samples; } \\
1 \text { strain from poultry and } 1 \text { strain from beef) }\end{array}$ \\
\hline Soyer et al. 2013 [55] & Human and bovine samples & $\begin{array}{l}336 \text { isolates (178 isolates from human and } \\
158 \text { isolates from bovine) }\end{array}$ \\
\hline Tajbakhsh et al. 2012 [56] & 1.120 samples of humans with diarrhea symptoms & 71 isolates $(6.4 \%)$ \\
\hline Thai et al. 2012 [57] & $\begin{array}{l}245 \text { pork and chicken meat shops samples (116 carcass, } \\
84 \text { table surfaces and } 45 \text { sewage effluent) }\end{array}$ & $\begin{array}{l}97 \text { isolates (51 strains from carcass; } 30 \text { strains from } \\
\text { table surfaces and } 16 \text { strains from sewage effluent) } \\
\qquad(39.6 \%)\end{array}$ \\
\hline Vital et al. 2017 [41] & 410 fresh vegetables samples & 24 isolates $(5.85 \%)$ \\
\hline Vuthy et al. 2017 [58] & $\begin{array}{l}762 \text { chicken samples ( } 80 \text { feces, } 82 \text { chicken caeca, } \\
440 \text { chicken neck skins, } 80 \text { rinse water and } 80 \text { chopping } \\
\text { boards samples selected inside chicken slaughter) }\end{array}$ & 181 isolates $(23.4 \%)$ \\
\hline Xu et al. 2019 [10] & Agricultural samples & 18 isolates \\
\hline Zhu et al. 2017 [43] & 627 broiler chicken samples & 189 isolates $(30.1 \%)$ \\
\hline Zhu et al. 2019 [59] & 324 pork meat samples & 155 isolates $(47.8 \%)$ \\
\hline Zishiri et al. 2016 [42] & 200 chicken samples & 102 isolates $(51.0 \%)$ \\
\hline
\end{tabular}

\section{Conclusions}

The results obtained in this study revealed that the tetracycline resistance genes most frequently isolated from Salmonella spp. were tet $A$ and tetB. The genes sul1 and sul 2 were the most frequently sulfonamide-resistant genes present in Salmonella. The chicken and pork samples presented the most significant number of these resistance genes. The intensive use of tetracycline and sulfonamides antibiotics in the production chain of these foods must have resulted in the development of this resistance. Bacterial resistance represents a 
significant public health concern, as there is a possibility of transferring resistance genes between humans, animals, and the environment.

Author Contributions: Conceptualization, I.C.R.d.S.; investigation, S.L.S.P., A.R.M.R. and A.C.A.d.O.F; writing - original draft preparation, S.L.S.P., A.C.A.d.O.F. and D.C.O.; writing-review and editing, C.M.d.S.S. and D.C.O.; supervision, I.C.R.d.S. and D.C.O.; funding acquisition, I.C.R.d.S., A.R.M.R. and D.C.O. All authors have read and agreed to the published version of the manuscript.

Funding: This research was funded by Coordenação de Aperfeiçoamento de Pessoal de Nível Superior, Brasil (CAPES) (Finance Code 001), by UnB (Edital DPI/DPG 1/2021) and by FAPDF (Fundação de Apoio à Pesquisa do Distrito Federal Edital 3/2018).

Conflicts of Interest: The authors declare no conflict of interest.

\section{References}

1. Adesoji, A.T.; Ogunjobi, A.A.; Olatoye, I.O.; Douglas, D.R. Prevalence of tetracycline resistance genes among multi-drug resistant bacteria from selected water distribution systems in southwestern Nigeria. Ann. Clin. Microbiol. Antimicrob. 2015, 14, 2-8. [CrossRef]

2. Marosevic, D.; Kaevska, M.; Jaglic, Z. Resistance to the tetracyclines and macrolide-lincosamide-streptogramin group of antibiotics and its genetic linkage-A review. Ann. Agric. Environ. Med. 2017, 24, 338-344. [CrossRef] [PubMed]

3. Sheykhsaran, E.; Baghi, H.B.; Soroush, M.H.; Ghotaslou, R. An overview of tetracyclines and related resistance mechanisms. Rev. Med. Microbiol. 2019, 30, 69-75. [CrossRef]

4. Grossman, T.H. Tetracycline antibiotics and resistance. Cold Spring Harb. Perspect. Med. 2016, 6, 1-24. [CrossRef] [PubMed]

5. Roberts, M.C.; Schwarz, S. Tetracycline and chloramphenicol resistance mechanisms. In Antimicrobial Drug Resistance; Meyers, D., Sobel, J., Ouellette, M., Kaye, K., Marchaim, D., Eds.; Springer: Berlin/Heidelberg, Germany, 2017; pp. $231-242$.

6. Hussain, T.; Jamal, M.; Nighat, F.; Andleeb, S. Broad spectrum antibiotics and resistance in nontarget bacteria: An example from tetracycline. J. Pure Appl. Microbiol. 2014, 8, 2667-2671.

7. Maka, L.; Mackiw, E.; Sciezynska, H.; Modzelewska, M.; Popowska, M. Resistance to sulfonamides and dissemination of sul genes among Salmonella spp. isolated from food in Poland. Foodborne Pathog. Dis. 2015, 12, 383-389. [CrossRef]

8. Sánchez-Osuna, M.; Cortés, P.; Barbé, J.; Erill, I. Origin of the mobile di-hydro-pteroate synthase gene determining sulfonamide resistance in clinical isolates. Front. Microbiol. 2019, 10,1-15. [CrossRef]

9. Sköld, O.E.; Swedberg, G. Sulfonamides and Trimethoprim. In Antimicrobial Drug Resistance; Mayers, D., Sobel, J., Ouellette, M., Kaye, K., Marchaim, D., Eds.; Springer: Berlin/Heidelberg, Germany, 2017; pp. 348-358.

10. Xu, F.; Min, F.; Wang, J.; Luo, Y.; Huang, S.; Chen, M.; Wu, R.; Zhang, Y. Development and evaluation of a Luminex xTAG assay for sulfonamide resistance genes in Escherichia coli and Salmonella isolates. Mol. Cell Probes. 2019, 49, 1-4. [CrossRef] [PubMed]

11. Nunes, O.C.; Manaia, C.M.; Kolvenbach, B.A.; Corvini, P.F. Living with sulfonamides: A diverse range of mechanisms observed in bacteria. Appl. Microbiol. Biotechnol. 2020, 104, 10389-10408. [CrossRef]

12. Christian, A.; Vivian, E.B.; Crystal, N.Z.; Frank, B.O. Antibiotic Use in Poultry Production and Its Effects on Bacterial Resistance. In Antimicrobial Resistance-A Global Threat; Kumar, Y., Ed.; IntechOpen: London, UK, 2018; pp. 33-51.

13. Lees, P.; Pelligand, L.; Giraud, E.; Toutain, P.L. A history of antimicrobial drugs in animals: Evolution and revolution. J. Vet. Pharmacol. Therap. 2021, 44, 137-171. [CrossRef]

14. Ben, W.W.; Wang, J.; Pan, X.; Qiang, Z.M. Dissemination of antibiotic resistance genes and their potential removal by on-farm treatment processes in nine swine feedlots in Shandong Province, China. Chemosphere 2017, 167, 262-268. [CrossRef]

15. Card, R.; Vaughan, K.; Bagnall, M.; Spiropoulos, J.; Cooley, W.; Strickland, T.; Rob, D.; Anjum, M.F. Virulence characterization of Salmonella enterica isolates of differing antimicrobial resistance recovered from UK livestock and imported meat samples. Front. Microbiol. 2016, 7, 1-11. [CrossRef] [PubMed]

16. Liu, Z.; Klümper, U.; Shi, L.; Ye, L.; Li, M. From pig breeding environment to subsequently produced pork: Comparative analysis of antibiotic resistance genes and bacterial community composition. Front. Microbiol. 2019, 10, 1-12. [CrossRef]

17. Yuan, J.; Ni, M.; Liu, M.; Zheng, Y.; Gu, Z. Occurrence of antibiotics and antibiotic resistance genes in a typical estuary aquaculture region of Hangzhou Bay, China. Mar. Pollut. Bull. 2019, 138, 376-384. [CrossRef] [PubMed]

18. Wang, N.; Yang, X.; Jiao, S.; Zhang, J.; Ye, B.; Gao, S. Sulfonamide resistant bacteria and their resistance genes in soils fertilized with manures from Jiangsu Province, Southeastern China. PLoS ONE 2014, 9, e112626. [CrossRef]

19. Jiang, H.; Cheng, H.; Liang, Y.; Yu, S.; Yu, T.; Fang, J.; Zhu, C. Diverse mobile genetic elements and conjugal transferability of sulfonamide resistance genes (sul1, sul2, and sul3) in Escherichia coli isolates from Penaeus vannamei and pork from large markets in Zhejiang, China. Front. Microbiol. 2019, 10, 1-10. [CrossRef] [PubMed]

20. Achermann, S.; Bianco, V.; Mansfeldt, C.B.; Vogler, B.; Kolvenbach, B.A.; Corvini, P.F.X.; Kathrin, F.K. Biotransformation of sulfonamide antibiotics in activated sludge: The formation of pterinconjugates leads to sustained risk. Environ. Sci. Technol. 2018, 52, 6265-6274. [CrossRef] [PubMed]

21. Deng, Y.; Mao, Y.; Li, B.; Yang, C.; Zhang, T. Aerobic degradation of sulfadiazine by Arthrobacter spp.: Kinetics, pathways, and genomic characterization. Environ. Sci. Technol. 2016, 50, 9566-9575. [CrossRef] [PubMed] 
22. Chen, J.; Xie, S. Overview of sulfonamide biodegradation and the relevant pathways and microorganisms. Sci. Total. Environ. 2018, 640, 1465-1477. [CrossRef] [PubMed]

23. Felis, E.; Kalka, J.; Sochacki, A.; Kowalska, K.; Bajkacz, S.; Harnisz, M.; Korzeniewska, E. Antimicrobial pharmaceuticals in the aquatic environment-occurrence and environmental implications. Eur. J. Pharmacol. 2020, 866, 172813. [CrossRef]

24. Nguyen, F.; Starosta, A.L.; Arenz, S.; Sohmen, D.; Dönhöfer, A.; Wilson, D.N. Tetracycline antibiotics and resistance mechanisms. Biol. Chem. 2014, 395, 1-24. [CrossRef]

25. Roberts, M.C.; Schwarz, S. Tetracycline and phenicol resistance genes and mechanisms: Importance for agriculture, the environment, and humans. J. Environ. Qual. 2016, 45, 576-592. [CrossRef]

26. Xu, X.; Biswas, S.; Gu, G.; Elbediwi, M.; Li, Y.; Yue, M. Characterization of multidrug resistance patterns of emerging Salmonella enterica serovar Rissen along the food chain in China. Antibiotics 2020, 9, 660. [CrossRef]

27. Dessie, H.K.; Bae, D.H.; Lee, Y.J. Characterization of integrons and their cassettes in Escherichia coli and Salmonella isolates from poultry in Korea. Poult. Sci. 2013, 92, 3036-3043. [CrossRef] [PubMed]

28. Maka, Ł.; Popowska, M. Antimicrobial resistance of Salmonella spp. isolated from food. Rocz. Panstw. Zakl. Hig. 2016, 67, 343-358.

29. McMillan, E.A.; Gupta, S.K.; Williams, L.E.; Jové, T.; Hiott, L.M.; Woodley, T.A.; Barrett, J.B.; Jackson, C.R.; Wasilenko, J.L.; Simmons, M.; et al. Antimicrobial resistance genes, cassettes, and plasmids present in Salmonella enterica associated with United States food animals. Front. Microbiol. 2019, 10, 1-18. [CrossRef] [PubMed]

30. Peruzy, M.F.; Capuano, F.; Proroga, Y.T.R.; Cristiano, D.N.; Carullo, M.R.; Murru, N. Antimicrobial susceptibility testing for Salmonella serovars isolated from food samples: Five-year monitoring (2015-2019). Antibiotics 2020, 9, 365. [CrossRef]

31. Perreten, V.; Boerlin, P. A new sulfonamide resistance gene (sul3) in Escherichia coli is widespread in the pig population of Switzerland. Antimicrob. Agents Chemother. 2003, 47, 1169-1172. [CrossRef]

32. Razavi, M.; Marathe, N.P.; Gillings, M.R.; Flach, C.F.; Kristiansson, E.; Joakim Larsson, D.G. Discovery of the fourth mobile sulfonamide resistance gene. Microbiome 2017, 5, 1-12. [CrossRef]

33. Guerra, B.; Junker, E.; Helmuth, R. Incidence of the recently described sulfonamide resistance gene sul3 among German Salmonella enterica strains isolated from livestock and food. Antimicrob. Agents Chemother. 2004, 48, 2712-2715. [CrossRef]

34. Heredia, N.; García, S. Animals as sources of food-borne pathogens: A review. Anim. Nutr. 2018, 4, 250-255. [CrossRef]

35. Ministério da Saúde do Brasil. Surto de Doenças Transmitidas por Alimentos no Brasil. Informe, 2018. Available online: http:/ / portalarquivos2.saude.gov.br/images/pdf/2019/maio/17/Apresentacao-Surtos-DTA-Maio-2019.pdf (accessed on 9 January 2021).

36. Hoffmann, S.; Maculloch, B.; Batz, M. Economic Burden of Major Foodborne Illnesses Acquired in the United States, EIB-140; US Department of Agriculture, Economic Research Service: Washington, DC, USA, 2015; pp. 543-616.

37. EFSA-ECDC. European Food Safety Authority and European Centre for Disease Prevention and Control. The European Union Summary Report on Antimicrobial Resistance in zoonotic and indicator bacteria from humans, animals and food in $2018 / 2019$. EFSA J. 2021, 19, 1-178.

38. Deng, W.; Quan, Y.; Yang, S.; Guo, L.; Zhang, X.; Liu, S.; Chen, S.; Zhou, K.; He, L.; Li, B.; et al. Antibiotic resistance in Salmonella from retail foods of animal origin and its association with disinfectant and heavy metal resistance. Microb. Drug Resist. 2018, 24, 782-791. [CrossRef] [PubMed]

39. Iwu, C.J.; Iweriebor, B.C.; Obi, L.C.; Basson, A.K.; Okoh, A.I. Multidrug-Resistant Salmonella isolates from swine in the Eastern Cape Province, South Africa. J. Food. Prot. 2016, 79, 1234-1239. [CrossRef] [PubMed]

40. Sadiq, M.B.; Tarning, J.; Cho, T.Z.A.; Anal, A.K. Antibacterial activities and possible modes of action of Acacia nilotica (L.) Del. against multidrug-resistant Escherichia coli and Salmonella. Molecules 2017, 22, 47. [CrossRef] [PubMed]

41. Vital, P.G.; Caballes, M.B.D.; Rivera, W.L. Antimicrobial resistance in Escherichia coli and Salmonella spp. isolates from fresh produce and the impact to food safety. J. Environ. Sci. Health 2017, 52, 683-689. [CrossRef] [PubMed]

42. Zishiri, O.T.; Mkhize, N.; Mukaratirwa, S. Prevalence of virulence and antimicrobial resistance genes in Salmonella spp. isolated from commercial chickens and human clinical isolates from South Africa and Brazil. Onderstepoort J. Vet. Res. 2016, 83, 1-11. [CrossRef]

43. Zhu, Y.; Lai, H.; Zow, L.; Yin, S.; Wang, C.; Han, X.; Xia, X.; Hu, K.; He, L.; Zhou, K.; et al. Antimicrobial resistance and resistance genes in Salmonella strains isolated from broiler chickens along the slaughtering process in China. Int. J. Food Microbiol. 2017, 259, 43-51. [CrossRef]

44. Igbinosa, I. Prevalence and detection of antibiotic-resistant determinant in Salmonella isolated from food-producing animals. Trop. Anim. Health Prod. 2014, 47, 37-43. [CrossRef]

45. Aslam, M.; Checkley, S.; Avery, B.; Chalmers, G.; Bohaychuk, V.; Gensler, G.; Reid-Smith, R.; Boerlin, P. Phenotypic and genetic characterization of antimicrobial resistance in Salmonella serovars isolated from retail meats in Alberta, Canada. Food Microbiol. 2012, 32, 110-117. [CrossRef]

46. Dahshan, H.; Chuma, T.; Shahada, F.; Akiba, M.; Fujimoto, H.; Akasaka, K.; Kamimura, Y.; Okamoto, K. Characterization of antibiotic resistance and the emergence of AmpC-producing Salmonella Infantis from pigs. J. Vet. Med. Sci. 2010, 72, 1437-1442. [CrossRef] [PubMed]

47. El-Sharkawy, H.; Tahoun, A.; El-Gohary, A.E.-G.A.; El-Abasy, M.; El-Khayat, F.; Gillespie, T.; Kitade, Y.; Hafez, H.M.; Neubauer, H.; El-Adawy, H. Epidemiological, molecular characterization and antibiotic resistance of Salmonella enterica serovars isolated from chicken farms in Egypt. Gut Pathog. 2017, 9, 8. [CrossRef] 
48. Hsu, C.Y.; Hsu, B.M.; Ji, W.T.; Chen, J.S.; Hsu, T.K.; Ji, D.D.; Tseng, S.F.; Chiu, Y.C.; Kao, P.M.; Huang, Y.L. Antibiotic resistance pattern and gene expression of non-typhoid Salmonella in riversheds. Environ. Sci. Pollut. Res. 2015, 22, 7843-7850. [CrossRef] [PubMed]

49. Khoshbakht, R.; Derakhshandeh, A.; Jelviz, L.; Azhdari, F. Tetracycline resistance genes in Salmonella enterica serovars with animal and human origin. Int. J. Enteric Pathog. 2018, 6, 60-64. [CrossRef]

50. Kozak, G.K.; Pearl, D.L.; Parkman, J.; Reid-Smith, R.J.; Deckert, A.; Boerlin, P. Distribution of sulfonamide resistance genes in Escherichia coli and Salmonella isolates from swine and chickens at abattoirs in Ontario and Quebec, Canada. Appl. Environ. Microb. 2009, 75, 5999-6001. [CrossRef]

51. Lapierre, L.; San Martín, B.; Araya-Jordán, C.; Borie, C. Comparison of integron-linked antibiotic resistance genes in strains of Salmonella spp. isolated from swine in Chile in 2005 and 2008. Can. J. Microbiol. 2010, 56, 515-521. [CrossRef] [PubMed]

52. Lopes, G.V.; Pissetti, C.; da Cruz, P.P.D.; da Silva, L.E.; Cardoso, M. Resistance phenotypes and genotypes of Salmonella enterica subsp. enterica isolates from feed, pigs, and carcasses in Brazil. J. Food Prot. 2015, 78, 407-413.

53. Márquez, F.M.L.; Burgos, M.J.G.; Pulido, R.P.; Gálvez, A.; López, R.L. Biocide tolerance and antibiotic resistance in Salmonella isolates from hen eggshells. Foodborne Pathog. Dis. 2017, 14, 89-95. [CrossRef]

54. Mthembu, T.P.; Zishiri, O.T.; El Zowalaty, M.E. Molecular detection of multidrug-resistant Salmonella isolated from livestock production systems in South Africa. Infect. Drug Resist. 2019, 12, 3537-3548. [CrossRef] [PubMed]

55. Soyer, Y.; Richards, J.; Hoelzer, K.; Warnick, L.D.; Fortes, E.; McDonough, P.; Dumas, N.B.; Grohn, Y.T.; Wiedmann, M. Antimicrobial drug resistance patterns among cattle-and human-associated Salmonella strains. J. Food. Prot. 2013, 76, 1676-1688. [CrossRef]

56. Tajbakhsh, M.; Hendriksen, R.S.; Nochi, Z.; Zali, M.R.; Aarestrup, F.M.; Garcia-Migura, L. Antimicrobial resistance in Salmonella spp. recovered from patients admitted to six different hospitals in Tehran, Iran from 2007 to 2008. Folia Microbiol. 2012, 57, 91-97. [CrossRef] [PubMed]

57. Thai, T.H.; Lan, N.T.; Hirai, T.; Yamaguchi, R. Antimicrobial resistance in Salmonella serovars isolated from meat shops at the markets in North Vietnam. Foodborne Pathog. Dis. 2012, 9, 986-991. [CrossRef]

58. Vuthy, Y.; Lay, K.S.; Seiha, H.; Kerleguer, A.; Aidara-Kane, A. Antibiotic susceptibility and molecular characterization of resistance genes among Escherichia coli and among Salmonella subsp. in chicken food chains. Asian Pac. J. Trop. Biomed. 2017, 7, 670-674. [CrossRef]

59. Zhu, A.; Zhi, W.; Qiu, Y.; Wei, L.; Tian, J.; Pan, Z.; Kang, X.; Gu, W.; Duan, L. Surveillance study of the prevalence and antimicrobial resistance of Salmonella in pork from open markets in Xuzhou, China. Food Control. 2019, 98, 474-480. [CrossRef]

60. Li, S.; Zhou, Y.; Miao, Z. Prevalence and antibiotic resistance of non-typhoidal Salmonella isolated from raw chicken carcasses of commercial broilers and spent hens in Tai'an, China. Front. Microbiol. 2017, 8, 2106. [CrossRef]

61. Li, Y.C.; Pan, Z.M.; Kang, X.L.; Geng, S.Z.; Liu, Z.Y.; Cai, Y.Q.; Jiao, X.A. Prevalence, characteristics, and antimicrobial resistance patterns of Salmonella in retail pork in Jiangsu province, eastern China. J. Food Prot. 2014, 77, 236-245. [CrossRef]

62. Dallal, M.M.S.; Doyle, M.P.; Rezadehbashi, M.; Dabiri, H.; Sanaei, M.; Modarresi, S. Prevalence and antimicrobial resistance profiles of Salmonella serotypes, Campylobacter and Yersinia spp. isolated from retail chicken and beef, Tehran, Iran. Food Control. 2010, 21, 388-392. [CrossRef]

63. Romero-Barrios, P.; Deckert, A.; Parmley, E.J.; Leclair, D. Antimicrobial resistance profiles of Escherichia coli and Salmonella isolates in Canadian broiler chickens and their products. Foodborne Pathog. Dis. 2020, 17, 672-678. [CrossRef]

64. Wang, X.; Biswas, S.; Paudyal, N.; Pan, H.; Li, X.; Fang, W.; Yue, M. Antibiotic resistance in Salmonella Typhimurium isolates recovered from the food chain through national antimicrobial resistance monitoring system between 1996 and 2016. Front. Microbiol. 2019, 10, 985. [CrossRef] [PubMed]

65. Xu, Y.; Zhou, X.; Jiang, Z.; Qi, Y.; Ed-Dra, A.; Yue, M. Epidemiological investigation and antimicrobial resistance profiles of Salmonella isolated from breeder chicken hatcheries in Henan, China. Front. Cell Infect. Microbiol. 2020, 10, 497. [CrossRef]

66. Moe, A.Z.; Paulsen, P.; Pichpol, D.; Fries, R.; Irsigler, H.; Baumann, M.P.O.; Oo, K.N. Prevalence and antimicrobial resistance of Salmonella isolates from chicken carcasses in retail markets in Yangon, Myanmar. J. Food. Prot. 2017, 80, 947-951. [CrossRef]

67. Terentjeva, M.; Avsejenko, J.; Streikisa, M.; Utinane, A.; Kovalenko, K.; Berzins, A. Prevalence and antimicrobial resistance of Salmonella in meat and meat products in Latvia. Ann. Agric. Environ. Med. 2017, 24, 317-321. [CrossRef]

68. Sodagari, H.R.; Mashak, Z.; Ghadimianazar, A. Prevalence and antimicrobial resistance of Salmonella serotypes isolated from retail chicken meat and giblets in Iran. J. Infect. Dev. Ctries. 2015, 9, 463-469. [CrossRef] [PubMed]

69. Zeng, Y.B.; Xiong, L.G.; Tan, M.F.; Li, H.Q.; Yan, H.; Zhang, L.; Yin, D.F.; Kang, Z.F.; Wei, Q.P.; Luo, L.G. Prevalence and antimicrobial resistance of Salmonella in pork, chicken, and duck from retail markets of China. Foodborne Pathog. Dis. 2019, 16, 339-345. [CrossRef]

70. Voss-Rech, D.; Potter, L.; Vaz, C.S.; Pereira, D.I.; Sangioni, L.A.; Vargas, Á.C.; de Avila Botton, S. Antimicrobial resistance in nontyphoidal Salmonella isolated from human and poultry-related samples in Brazil: 20-Year Meta-Analysis. Foodborne Pathog. Dis. 2017, 14, 116-124. [CrossRef] [PubMed]

71. Vaez, H.; Ghanbari, F.; Sahebkar, A.; Khademi, F. Antibiotic resistance profiles of Salmonella serotypes isolated from animals in Iran: A meta-analysis. Iran. J. Vet. Res. 2020, 21, 188-197.

72. Zhang, C.M.; Xu, L.M.; Mou, X.; Xu, H.; Liu, J.; Miao, Y.H.; Xiaochang, C.; Wang, X.L. Characterization and evolution of antibiotic resistance of Salmonella in municipal wastewater treatment plants. J. Environ. Manag. 2019, 251, 109547. [CrossRef] [PubMed] 
73. Zhang, C.M.; Du, C.; Xu, H.; Miao, Y.H.; Cheng, Y.Y.; Tang, H.; Zhou, J.H.; Wang, X.C. Occurrence of tetracycline-resistant fecal coliforms and their resistance genes in an urban river impacted by municipal wastewater treatment plant discharges. J. Environ. Sci. Health A 2015, 50, 744-749. [CrossRef]

74. Mattiello, S.P.; Drescher, G.; Barth, V.C.; Ferreira, C.A.; Oliveira, S.D. Characterization of antimicrobial resistance in Salmonella enterica strains isolated from Brazilian poultry production. Antonie Van Leeuwenhoek. 2015, 108, 1227-1238. [CrossRef]

75. Sanchez-Maldonado, A.F.; Aslam, M.; Service, C.; Narváez-Bravo, C.; Avery, B.P.; Johnson, R.; Jones, T.H. Prevalence and antimicrobial resistance of Salmonella isolated from two pork processing plants in Alberta, Canada. Int. J. Food Microbiol. 2017, 241, 49-59. [CrossRef]

76. Chopra, I.; Roberts, M. Tetracycline antibiotics: Mode of action, applications, molecular biology, and epidemiology of bacterial resistance. Microbiol. Mol. Biol. Rev. 2001, 65, 232-260. [CrossRef] [PubMed]

77. Thaker, M.; Spanogiannopoulos, P.; Wright, G.D. The tetracycline resistome. Cell Mol. Life Sci. 2010, 67, 419-431. [CrossRef]

78. Ma, S.; Lei, C.; Kong, L.; Jiang, W.; Liu, B.; Men, S.; Yang, Y.; Cheng, G.; Chen, Y.; Wang, H. Prevalence, antimicrobial resistance, and relatedness of Salmonella isolated from chickens and pigs on farms, abattoirs, and markets in Sichuan Province, China. Foodborne Pathog. Dis. 2017, 14, 667-677. [CrossRef] [PubMed]

79. Machado, E.; Coque, T.M.; Cantón, R.; Sousa, J.C.; Peixe, L. Commensal Enterobacteriaceae as reservoirs of extended-spectrum beta-lactamases, integrons, and sul genes in Portugal. Front. Microbiol. 2013, 4, 80. [CrossRef] [PubMed]

80. Zhang, T.; Wang, C.G.; Zhong, X.H. Survey on sulfonamide antibiotic-resistant genotype and phenotype of avian Escherichia coli in North China. Poult. Sci. 2012, 91, 884-887. [CrossRef]

81. Deekshit, V.K.; Kumar, B.K.; Rai, P.; Srikumar, S.; Karunasagar, I. Detection of class 1 integrons in Salmonella Weltevreden and silent antibiotic resistance genes in some seafood-associated nontyphoidal isolates of Salmonella in south-west coast of India. J. Appl. Microbiol. 2012, 112, 1113-1122. [CrossRef]

82. Roberts, M.C.; Kuchmiy, E.; Miranda, C.D. The tetracycline resistant tet gene identified in three new genera of bacteria isolated in 1999 from Chilean salmon farms. J. Antimicrob. Chemother. 2015, 70, 619-620. [CrossRef]

83. Sánchez-Vargas, F.M.; Abu-El-Haija, M.A.; Gómez-Duarte, O.G. Salmonella infections: An update on epidemiology, management, and prevention. Travel Med. Infect. Dis. 2011, 9, 263-277. [CrossRef]

84. Ljubojević, D.; Pelić, M.; Puvača, N.; Milanov, D. Resistance to tetracycline in Escherichia coli isolates from poultry meat: Epidemiology, policy and perspective. World's Poult. Sci. J. 2017, 73, 409-417. [CrossRef]

85. Adesiji, Y.O.; Deekshit, V.K.; Karunasagar, I. Antimicrobial-resistant genes associated with Salmonella spp. isolated from human, poultry, and seafood sources. Food Sci. Nutr. 2014, 2, 436-442. [CrossRef]

86. Lorenz, T.C. Polymerase chain reaction: Basic protocol plus troubleshooting and optimization strategies. J. Vis. Exp. 2012, 63, 1-15. [CrossRef] [PubMed]

87. Ye, J.; Coulouris, G.; Zaretskaya, I.; Cutcutache, I.; Rozen, S.; Madden, T. Primer-BLAST: A tool to design target-specific primers for polymerase chain reaction. BMC Bioinform. 2012, 13, 2-11. [CrossRef]

88. Śpibida, M.; Krawczyk, B.; Olszewski, M.; Kur, J. Modified DNA polymerases for PCR troubleshooting. J. Appl. Genet. 2017, 58, 133-142. [CrossRef] [PubMed]

89. Helke, K.L.; McCrackin, M.A.; Galloway, A.M.; Poole, A.Z.; Salgado, C.D.; Marriott, B.P. Effects of antimicrobial use in agricultural animals on drug-resistant foodborne salmonellosis in humans: A systematic literature review. Crit. Rev. Food. Sci. Nutr. 2017, 11, 472-488. [CrossRef] [PubMed]

90. Antunes, P.; Mourão, J.; Campos, J.; Peixe, L. Salmonellosis: The role of poultry meat. Clin. Microbiol. Infect. 2016, $22,110-121$. [CrossRef]

91. Ren, X.; Li, M.; Xu, C.; Cui, K.; Feng, Z.; Fu, Y.; Zhang, J.; Liao, M. Prevalence and molecular characterization of Salmonella enterica isolates throughout an integrated broiler supply chain in China. Epidemiol. Infect. 2016, 144, 2989-2999. [CrossRef] [PubMed]

92. Choi, S.W.; Ha, J.S.; Kim, B.Y.; Lee, D.H.; Park, J.K.; Youn, H.N.; Hong, Y.H.; Lee, S.B.; Lee, J.B.; Park, S.Y.; et al. Prevalence and characterization of Salmonella species in entire steps of a single integrated broiler supply chain in Korea. Poul. Sci. 2014, 93, 1251-1257. [CrossRef] [PubMed]

93. Nakao, J.H.; Pringle, J.; Jones, R.W.; Nix, B.E.; Borders, J.; Heseltine, G.; Gomez, T.M.; McCluskey, B.; Roney, C.S.; Brinson, D.; et al. 'One Health' investigation: Outbreak of human Salmonella Braenderup infections traced to a mail-order hatchery-United States, 2012-2013. Epidemiol. Infect. 2015, 143, 2178-2186. [CrossRef]

94. Paine, S.; Thornley, C.; Wilson, M.; Dufour, M.; Sexton, K.; Miller, J. An outbreak of multiple serotypes of Salmonella in New Zealand linked to consumption of contaminated tahini imported from Turkey. Foodborne Pathog. Dis. 2014, 11, 887-892. [CrossRef] [PubMed]

95. Li, B.; Yang, X.; Tan, H.; Ke, B.; He, D.; Wang, H. Whole genome sequencing analysis of Salmonella enterica serovar Weltevreden isolated from human stool and contaminated food samples collected from the Southern coastal area of China. Int. J. Food Microbiol. 2018, 266, 317-323. [CrossRef]

96. Miller, A.J.; Twomey, D.F.; Davies, R.H.; Teale, C.J.; Williamson, S.M.; Reichel, R.; Featherstone, C.A.; Cook, A.J.; Snow, L.C.; Armstrong, J.D. Salmonella serovars and antimicrobial resistance patterns on a sample of high seroprevalence pig farms in England and Wales (2003-2008). Zoonoses Public Health 2011, 58, 549-559. [CrossRef]

97. Bier, D.; Kich, J.D.; Duarte, S.C.; Silva, M.R.; Valsoni, L.M.; Ramos, C.A.N.; Rodrigues, D.P.; Araújo, F.R. Survey of Salmonella spp. in beef meat for export at slaughterhouses in Brazil. Pesq. Vet. Bras. 2018, 38, 2037-2043. [CrossRef] 
98. Castro-Vargas, R.E.; Herrera-Sánchez, M.P.; Rodríguez-Hernández, R.; Rondón-Barragán, I.S. Antibiotic resistance in Salmonella spp. isolated from poultry: A global overview. Vet. World. 2020, 13, 2070-2084. [PubMed]

99. McDermott, P.F.; Zhao, S.; Tate, H. Antimicrobial resistance in nontyphoidal Salmonella. Microbiol. Spectrum. 2018, 6, 780-790. [CrossRef] [PubMed]

100. Brasil, Lista de Substâncias Proibidas e Legislação Correspondente. 2017. Available online: http://www.agricultura.gov.br/ assuntos/insumos-agropecuarios/insumos-pecuarios/arquivos-de-insumos-pecuarios/Substnciasproibidas.pdf (accessed on 9 January 2021).

101. Eng, S.K.; Pusparajah, P.; Mutalib, N.-A.S.; Ser, H.; Chan, K.; Lee, L.-H. Salmonella: A review on pathogenesis, epidemiology and antibiotic resistance. Front. Life Sci. 2015, 8, 284-293.

102. Fair, R.J.; Tor, Y. Perspectives in medicinal chemistry antibiotics and bacterial resistance in the 21st century. Perspect. Med. Chem. 2014, 6, 25-64.

103. Jajere, S.M. A review of Salmonella enterica with particular focus on the pathogenicity and virulence factors, host specificity and antimicrobial resistance including multidrug resistance. Vet. World. 2019, 12, 504-521. [CrossRef]

104. Bengtsson, B.; Greko, C. Antibiotic resistance-consequences for animal health, welfare, and food production. Upsala J. Med. Sci. 2014, 119, 96-102. [CrossRef] [PubMed]

105. Pan, H.; Paudyal, N.; Li, X.; Fang, W.; Yue, M. Multiple food animal- borne route in transmission of antibiotic-resistant Salmonella Newport to humans. Front. Microbiol. 2018, 9, 23. [CrossRef] 